\title{
Atuação da Delegação Brasileira na Formulação do Acordo Internacional de Bretton Woods (1942-1944)
}

Resumo: $O$ presente artigo tem por objetivo investigar pensamento e ação dos delegados brasileiros na Conferência Monetária e Financeira das Nações Unidas, realizada em Bretton Woods, em julho de 1944, com destaque para a atuação de Octavio Gouvea de Bulhões, de Eugênio Gudin, e do Ministro Souza Costa. Analisa-se a visão brasileira acerca da nova ordem financeira internacional em construção, e suas estratégias pragmáticas de alinhamento com os interesses em choque durante a Conferência, particularmente organizados segundo as propostas do Plano White (norte-americano) e do Plano Keynes (britânico). Conclui-se que, apesar de incapaz de impedir a aprovação quase que integral do Plano White, a delegação brasileira foi capaz de garantir espaço para o Brasil na gestão no aparato econômico institucional criado em Bretton Woods.

Palavras-chave: Bretton Woods; Eugenio Gudin; Octavio Bulhões; Souza Costa; Economia internacional.

\section{Os Desafios da Construção de uma Nova Ordem Econômica Internacional}

No início de julho de 1944, os primeiros cinco mil soldados da Força Expedicionária Brasileira encontravam-se a bordo do USNS General Mann a caminho de Nápoles, dando o passo inicial para o esforço de guerra do Brasil contra as forças do Eixo.

- Doutor em História pela UFF. Professor Adjunto de História Econômica - Instituto de Economia - UFRJ - 22290-240 - Rio de Janeiro -RJ - Brasil. E-mail: daniel.barreiros@ie.ufrj.br 
Tal fato marcava o desfecho de um conjunto de pressões e contra-pressões que, desde 1939, atuavam sobre o governo do Estado Novo, na busca de um claro posicionamento em relação à ameaça nazi-fascista. Contudo, o desafio militar não era o único que se impunha ao Brasil àquela altura. Ainda que, no geral, os anos de guerra tenham sido marcados pela total estagnação no ingresso de capitais estrangeiros privados (em cifra congelada em torno de US\$ 700 milhões), medidas liberalizantes assumidas por Vargas e pelo ministério Sousa Costa, em 1941-1942, permitiram a flexibilização dos fluxos de saída de capitais, viabilizando a repatriação de lucros. Tal fato criara certo otimismo quanto às relações econômicas entre Brasil e Estados Unidos, na medida em que expandiu notoriamente o ingresso de capitais a partir de 1943. Entretanto, ao passo em que ficava mais clara a vitória aliada, a atitude orientada pela "boa vizinhança" fora sendo sucedida por negociações comerciais e financeiras cada vez menos flexíveis. Ao recusarem o reajuste dos preços do café, ao se demonstrarem progressivamente avessos ao processo de substituição de importações, e ao descumprirem a promessa feita durante os primeiros anos da guerra, do suprimento de matérias-primas e bens intermediários e de capital fundamentais para o processo de industrialização brasileiro, o Estado norte-americano despontava no horizonte como um formidável desafio a inserção do Brasil na nova ordem econômico-financeira internacional, que deveria ser gerida tão logo a paz se estabelecesse. Era percebido como de fundamental importância que o Brasil estivesse presente nas negociações sobre o futuro do sistema econômico mundial e, respeitando sua questionável capacidade de barganha, tentar obter o máximo de concessões em um provável (e confirmado) cenário de irrestrita hegemonia econômica dos EUA no bloco ocidental.

O processo de delimitação desta nova ordem econômica antecedeu a derrota alemã. Na retórica dos grandes estadistas e pensadores econômicos do Ocidente, notava-se uma séria preocupação em torno da reconstrução do sistema econômico internacional, de modo a pôr fim ao crônico quadro de instabilidade reinante no Entre-Guerras, que a despeito de ter 
sido palco de trinta conferências e reuniões internacionais com objetivo de estabelecer princípios coerentes de cooperação econômica entre as nações, foi devassado pelo crack da NYSE, em outubro de 1929, e pela conseqüente Grande Depressão, cujos reflexos se estenderam por toda a década de 1930. Não era rara entre os contemporâneos a consciência de que as rivalidades econômicas entre os Estados nacionais, a generalização de políticas comerciais orientadas pelo protecionismo e a incontornável dívida alemã, decretada em Versalhes, havia tornado o ambiente econômico internacional criticamente instável, o que estaria inegavelmente entre os principais fatores para a Grande Guerra.

Assim, no panorama dos esforços diplomáticos que marcaram todo o período de beligerância (desde a negociação da Carta do Atlântico em agosto de 1941), convergiam os policymakers aliados para a necessidade da criação de um sistema de cooperação internacional fortemente institucionalizado, para além dos mecanismos de ação política já previstos para as Nações Unidas. Este sistema deveria ser vigiado e regulado por um instrumento institucional capaz de assegurar a liquidez do sistema internacional, impedindo que novas crises nas contas externas dos países associados viessem a provocar perturbações no sistema de trocas e pagamentos. Bretton Woods, aldeia bucólica nas montanhas de New Hampshire, foi escolhida, então, como cenário para as negociações que traçariam o rumo da reconstrução da economia capitalista mundial. Tinha início, então, em Julho de 1944, a Conferência Monetária e Financeira das Nações Unidas. O principal desafio a ser enfrentado pelas delegações reunidas era o de ultrapassar os entraves e resquícios deixados pelas instituições falidas no Entre-Guerras, sem que isso significasse prejuízo significativo na projeção internacional de seus estados. Evidentemente, era algo que se aproximava de um jogo de soma zero: ao velho hegemon cabia lutar pela manutenção de seu espaço; ao novo, garantir que as condições excepcionais desfrutadas durante o conflito mundial fossem preservadas. Aos demais países, à despeito de suas alianças e afinidades, cabia 
obter o maior número de concessões possíveis a partir do embate dos gigantes.

Em certa medida importantes estudiosos da questão concordam que a Conferência de Bretton Woods não deve ser entendida como um momento intelectualmente crucial no processo de edificação das instituições econômicas internacionais do pós-guerra, visto que os principais parâmetros que redefiniriam o sistema já haviam sido formulados em negociações prévias. Ainda que estas negociações entre os Estados Unidos e o Reino Unido, iniciadas nos momentos iniciais do conflito mundial, não tenham tido qualquer caráter conclusivo, legaram aos delegados presentes em New Hampshire uma súmula do resultado do choque entre interesses britânicos e norte-americanos, a partir da qual lançar-se-iam os players com menor poder relativo no sistema, na busca de eventuais concessões. Nas palavras de Solomon, temos que "quando a paz foi restaurada, em 1945, já havia acordo quanto aos esboços do sistema monetário internacional do pós-guerra" (SOLOMON, 1979: 23). Ao atestar o fato, é possível sugerir que as discussões e embates na Conferência de Bretton Woods não consubstanciaram um momento-chave na disputa entre britânicos e norte-americanos - nítidos protagonistas do processo de reconstrução da economia internacional -, mas sim o palco onde foram conduzidos, de modo pragmático, ajustes em um proposta anteriormente pactuada de modo praticamente bilateral.

A Conferência de Bretton Woods foi, assim, um evento eminentemente político, a despeito de sua associação evidente com a dimensão "econômica" do processo histórico. Transparece a idéia de que sua realização foi engendrada pela manifesta pertinência de se obter legitimidade multilateral para um arcabouço institucional acordado entre duas potências, o que, se por um lado, abria a possibilidade de obtenção de conquistas pontuais e concessões dos demais países sobre o novo hegemon; por outro, não funcionava como fórum amplo a partir do qual diferentes concepções acerca do sistema econômico mundial pudessem ser contrapostas. Se temos que a Conferência "deixou 
ATUAÇÃO DA DELEGAÇÃO BRASILEIRA NA FORMULAÇÃO...

manifesta a clara hegemonia norte-americana no bloco dos países centrais, que se traduzia na conseguinte definição do reordenamento financeiro internacional" (LICHTENSZTEJN e BAER, 1987: 25), tal não significou a impossibilidade de ajustes pontuais, fosse por parte do Reino Unido, nação mais capaz de pressionar os EUA por concessões, fosse por parte de outros países do centro capitalista ou mesmo periféricos.

Norte-americanos e britânicos iniciaram as trocas preliminares de idéias sobre a configuração do novo sistema econômico internacional ainda no ano de 1942, com base nas propostas elaboradas por John Maynard Keynes e Harry Dexter White, "e das negociações que se seguiram surgiu uma proposta conciliatória" (SOLOMON, 1979: 24), que seria assinada por quarenta e quatro nações em Bretton Woods, mas não ratificada por todas. Assim temos que os planos rivais de Keynes e White foram "progressivamente refinados ao longo de uma série de modificações" e "as versões finais, publicadas em 1943, formaram a base da Declaração Conjunta dos especialistas britânicos e norte-americanos e dos Artigos de Acordo do Fundo Monetário Internacional" (EICHENGREEN, 2000: 135). A assimetria entre o poder de barganha das duas nações ficou expressa no fato de que, apesar de terem sido fruto de uma "postura de concessão mútua", os Artigos do Acordo foram aprovados estabelecendo quotas de participação no Fundo Monetário Internacional de US\$ 8 bilhões, valor próximo daquele fixado no Plano White (que previa US\$ 5 bi) e distante do que pretendia Keynes (US\$ 26 bilhões). Da mesma forma, os termos pactuados na Conferência de Bretton Woods determinavam obrigação mútua do Estado norte-americano da ordem de US\$ 2,7 bilhões, próxima da concepção prévia de Dexter White na qual foram propostas US\$ 2 bilhões, bastante distante daquilo que desejaram os britânicos (US\$ 23 bilhões). (EICHENGREEN, 2000: 136).

Os acordos financeiros concluídos em Bretton Woods não levaram em conta as especificidades do processo de reconstrução européia. Neles, é nítida a postura norte-americana no que concerne à defesa do livre mercado como mecanismo 
suficiente para a superação da destruição causada pela guerra, e redirecionar as economias capitalistas do Ocidente rumo ao crescimento sustentado.

A defesa do livre comércio pelo governo dos Estados Unidos tinha o apoio da indústria norte-americana, que considerava os mercados externos vitais para a prosperidade no pós-guerra e enxergava o sistema britânico de preferência imperial como um obstáculo ao acesso dos norte-americanos aos mercados (EICHENGREEN, 2000: 138).

Sem dúvida os planejadores monetários do pós-guerra subestimaram as enormes dificuldades a serem enfrentadas pela Europa.

(...) o plano para o qual conseguiram acordo não se destinava a contornar os problemas imediatos do pós-guerra, de alívio e reconstrução. Tampouco previram o atrito político que se revelaria entre a União Soviética e seus aliados na guerra" (SOLOMON, 1979: 24).

Não havia clareza no posicionamento dos formuladores de política norte-americanos acerca das cruciais diferenças manifestadas entre as sociedades democráticas e a URSS. "As políticas econômicas procuravam promover o livre comércio externo e interno através de grandes, e em última hipótese, intransponíveis abismos em instituições econômicas" (NAU, 1992: 95). Os Estados Unidos foram bem-sucedidos em evitar que as discussões em torno da criação do Fundo Monetário Internacional e do Banco Mundial acabassem "saindo dos trilhos", expandindo a idéia de "reconstrução" (recomposição das economias européias destruídas) para a idéia de "fomento" (o que poderia transformar as duas instituições em suporte para estratégias de desenvolvimento, mesmo em economias não destruídas pela guerra), tal como propuseram inutilmente alguns países subdesenvolvidos como o México (LICHTENSZTEJN e BAER, 1987: 34).

Decerto o "erro" perpetrado pelos planejadores econômicos 
nos EUA no que se refere às necessidades européias fora agravado pela manifesta crença no livre-mercado, que em nenhum momento nos autoriza a ver a postura da diplomacia norte-americana naquele julho de 1944 como sendo a de "exportar o New Deal". Considerando o espectro de visões econômicas em choque entre os principais membros do staff de F.D. Roosevelt, prevaleceu, no que diz respeito aos acordos de Bretton Woods, a perspectiva de aceitar apenas um de vários "dogmas intervencionistas" defendidos pelos new dealers, qual seja,

a idéia de que a política fiscal devia ser estabelecida de tal maneira que os déficits aumentassem e atuassem como estabilizadores automáticos em épocas de recessão, mas pequenos superávits resultassem em ocasiões de alta (não plena) taxa de emprego e fossem usados para resgatar a dívida nacional (NAU, 1992: 96).

Assim, entendiam que o comércio deveria ser o "combustível da recuperação", a partir do qual a Europa, sem políticas de estímulo à demanda, deveria ser capaz de obter a produtividade necessária para a geração de divisas com as quais pagaria pelas matérias-primas e bens de capital importados (EICHENGREEN, 2000: 138).

A respeito dos resultados obtidos na Conferência de Bretton Woods, a resposta remonta ao principal tema que englobou as discussões, e mais relevante ponto de atrito entre os Planos Keynes e White: a definição do que poderia ser aceito como dinheiro e meio de pagamento internacional, e como regular a quantidade e a confiabilidade desta mercadoria. Assume-se que no corpo do Plano White se delineava uma visão amplamente conservadora do sistema monetário internacional, que superou em pouco o finado padrão libra-ouro. Entende-se ainda que se este padrão fosse implementado na ausência de instituições reguladoras, suas chances de conferir estabilidade e confiabilidade nos intercâmbios internacionais estariam condicionadas às mesmas dificuldades enfrentadas outrora pela 
libra, visto que persistiriam problemas conjunturais relacionados aos balanços de pagamentos (LICHTENSZTEJN e BAER, 1987: 29). Assim temos que, em busca desta estabilidade, a principal conquista da Conferência foi a de, juntamente com a restauração do padrão-ouro (o que não foi considerado exatamente uma "conquista" por muitos delegados presentes no Mount Washington Hotel), gerar um código de conduta para as políticas econômicas daquelas nações desafiadas por desequilíbrios em suas contas externas, e para tal "institucionalizar diversas modalidades de empréstimo e mediação financeira entre os organismos criados [na Conferência], os governos nacionais e o sistema de bancos privados internacionais" (LICHTENSZTEJN e BAER, 1987: 25).

Os resultados da Conferência também estiveram intimamente ligados às expectativas manifestadas pelos círculos financeiros conservadores americanos. É sabido que estes exerceram pressão direta durante todo o processo de pactuação entre norte-americanos e britânicos, e especialmente durante os trabalhos no julho de 1944. As advertências do Secretário do Tesouro Hans Morgenthau, chefe da delegação norte-americana, acerca do perigo representado pela pressão exercida pelo setor financeiro, não foram suficientes para impedir que tentassem influenciar a elaboração do Plano White no que tange a "regressar a uma disciplina próxima à do padrão-ouro, ou aderir clara e simplesmente a uma moeda-chave (o padrão dólar)" (LICHTENSZTEJN e BAER, 1987: 26). Assim, enquanto o Reino Unido e os países europeus no geral buscavam interferir nos termos a serem pactuados de modo a criar condições favoráveis para a estabilização de suas balanças de pagamento debilitadas pelas necessidades da guerra mundial, a delegação norteamericana era pressionada em favor da defesa da consolidação do poderio financeiro norte-americano desenvolvido em decorrência do conflito (LICHTENSZTEJN e BAER, 1987: 27). 
ATUAÇÃO DA DELEGAÇÃO BRASILEIRA NA FORMULAÇÃO...

\section{Visões sobre o futuro da economia mundial: o Plano White e o Plano Keynes}

Que objetivos específicos trouxeram para New Hampshire os representantes britânicos, capitaneados por Lord Keynes, e o que efetivamente obtiveram à conclusão dos encontros? Embora o próprio plano Keynes não tenha recebido apoio incondicional do governo inglês, era objetivo da coroa britânica reorganizar a ordem mundial de modo a obter vantagens para sua economia nacional e mantê-la em superioridade no sistema em criação. Este objetivo, contudo, foi fartamente frustrado em função da estreita margem de manobra desfrutada por todos os Estados capitalistas diante do evidente poder imperial (e não hegemônico, neste momento) norte-americano.

(...) a Grã-Bretanha não conseguiu impor quase nenhum dos seus pontos de vista. Bretton Woods foi certa e definitivamente um triunfo total do poder dominante americano, expresso no Plano White", e neste sentido "(...) seus acordos foram o produto de uma negociação desigual entre o Estado norte-americano e o da Grã-Bretanha (...) dentro de um quadro fictício de cooperação mundial (LICHTENSZTEJN e BAER, 1987: 28).

As demandas inglesas foram sendo rechaçadas pelos norte-americanos mesmo antes da Conferência, ao ponto de nela terem de recuar à uma posição defensiva e pragmática, o que significava apenas preservar vantagens imediatas. Por exemplo,

Nos termos da Carta do Atlântico de agosto de 1941 e do Acordo de Ajuda Mútua de fevereiro de 1942, os britânicos assumiram o compromisso de restaurar a conversibilidade da libra na conta corrente e aceitaram o princípio da não-discriminação comercial",

fato este que estava plenamente de acordo com a concepção de sistema econômico internacional demandada pelos Estados Unidos, "em troca das promessas americanas de oferecer ajuda financeira em termos favoráveis e de respeitar a prioridade que os britânicos atribuíam ao pleno emprego" (EICHENGREEN, 
2000: 134). Neste sentido, entendemos então que "Bretton Woods (...) foi um processo crescentemente condicionado pelas concessões particulares que tal país [o Reino Unido] foi obtendo, como compensação, em uma relação de forças claramente desigual" (LICHTENSZTEJN e BAER, 1987: 28).

O Plano White foi o instrumento de afirmação da concepção de sistema econômico internacional norte-americana. Enquanto Keynes propunha um plano que visava "estabelecer um sistema totalmente reformado", a proposta de White revelou, sobretudo, a visão da elite financeira norte-americana que temia a aprovação de instrumentos em Bretton Woods que fizessem com que os cofres americanos "viessem a proporcionar recursos ilimitados para o resto do mundo", e por isso "se mostravam cautelosos e conservadores ao encarar as inovações propostas que saíam do escritório de Keynes no Tesouro Inglês" (SOLOMON, 1979: 25).

O Plano White deu o tom da resolução do problema do padrão monetário, restabelecendo o ouro como instrumento de reserva internacional. Argumentando contudo que a disponibilidade do metal seria escassa para as necessidades monetárias do mundo, acordou-se que toda moeda nacional poderia adquirir o status de meio de pagamento internacional desde que fosse conversível em ouro. A formação do Fundo requereria ouro, mas a proporção maior seria de moedas conversíveis.

No entanto, no cenário do pós-guerra, esse princípio encobria um privilégio, posto que os Estados Unidos concentravam a maior parte do ouro existente e contavam com um comércio exterior fortemente superavitário. Era, pois, de fato, o único país que podia manter a convertibilidade de sua moeda em ouro, o que tornava o dólar a divisa-chave e a moeda de reserva obrigatória (LICHTENSZTEJN e BAER, 1987: 29).

Contudo, o sistema que se propunha a partir do Plano White afastava-se do padrão ouro-divisas em três aspectos fundamentais: a) no que tange a questão do câmbio fixo, 
assumia-se a possibilidade de ajustes a partir da existência de "desequilíbrios fundamentais" nos balanços de pagamentos, critério este que não seria definido em nenhum momento posterior à Conferência de Bretton Woods; b) foram aceitos controles tendo em vista a limitação dos fluxos de capital volátil, responsáveis pela crise dos anos 1930; c) foi proposta a criação de instituições internacionais com o objetivo de monitorar as políticas econômicas nacionais e oferecer financiamento para equilibrar balanços de pagamento em situações de risco (EICHENGREEN, 2000: 131). A propósito, no médio prazo, "Os controles de capital constituíram-se no único elemento que funcionou mais ou menos segundo planejado (...) Este foi um período em que os governos fizeram abrangentes intervenções em sua economias e em seus sistemas financeiros" (EICHENGREEN, 2000: 132)

Acerca do câmbio fixo, mas ajustável, previsto por Dexter White, estabelecia-se que uma moeda nacional poderia ter sua paridade deslocada do preço pactuado multilateralmente em até $1 \%$, sem suscitar advertências ou represálias por parte das instituições de controle internacionais ou de outras nações; aliás, tanto Keynes quanto White rejeitaram "restrições impostas ao comércio internacional e suas formas de pagamento, repudiando as práticas cambiais discriminatórias" (LICHTENSZTEJN e BAER, 1987: 31), o que significava dizer que a eventual "desobediência" de um determinado Estado no que diz respeito às "regras do jogo" no novo sistema internacional não deveria ser punida bilateralmente, e sim através da ação dos órgãos reguladores do sistema. "O câmbio ajustável era um instrumento para eliminar déficits no balanço de pagamentos uma alternativa aos aumentos deflacionários nas taxas de redesconto dos bancos centrais, algo que se revelara tão doloroso no período entre-guerras". (EICHENGREEN, 2000: 132). Quaisquer alterações superiores a $1 \%$ deveriam ser justificadas pelos tomadores de decisão, e caso fosse planejada uma alteração cambial que se afastasse em mais de $10 \%$ do valor fixo pactuado, seria preciso a consulta prévia e estudos por parte das instituições de controle do sistema (LICHTENSZTEJN e BAER, 
1987: 31).

A insistência dos norte-americanos na adoção de um sistema de paridades fixas, cujas taxas sofreriam modificações substanciais apenas sob aprovação do FMI, pretendia evitar o tipo de instabilidade monetária internacional que prejudicaria a reconstrução dos sistemas de comércio (EICHENGREEN, 2000: 138).

Estes foram os princípios firmados em Bretton Woods. Poucas concessões foram feitas ao Plano Keynes. Nele, apresentava-se a proposta de criação de uma "União Internacional de Compensações", instituição que gerenciaria os instrumentos de troca e reserva de valor internacional, tendo ainda o papel de assegurar o cumprimento das regras no que diz respeito às questões financeiras, bem como atuar como emprestador de última instância em âmbito mundial para países com dificuldades em seu balanço de pagamentos. Na medida em que as políticas econômicas nacionais atentassem para a coordenação exercida pela União Internacional de Compensações, seria possível para os estados componentes do sistema "modificar suas taxas de câmbio e adotar restrições cambiais e comerciais conforme necessário para compatibilizar o pleno emprego com o equilíbrio no balanço de pagamentos", enquanto nos termos pactuados em Bretton Woods ficava previsto "um mundo de paridades fixas sob a supervisão de uma instituição internacional com poder de veto sobre mudanças nessas paridades" (EICHENGREEN, 2000: 135).

Através da eventual adoção do Plano Keynes deveria ser criada uma nova forma de dinheiro, denominada bancor, que substituiria o ouro como meio de troca e reserva de valor internacional, mas que seria conversível a este metal através de cotação fixa, mas corrigível conjunturalmente. O bancor seria uma moeda nominal, a partir da qual as transações externas seriam feitas. A moeda não seria depositada, contudo, em contas correntes sob a jurisdição de um estado nacional específico, e sim, em um organismo internacional com a função de gerenciar o 
ATUAÇÃO DA DELEGAÇÃO BRASILEIRA NA FORMULAÇÃO...

sistema. Segundo a proposta, as nações teriam contas-corrente nas quais as receitas de suas trocas externas seriam depositadas, e de onde sairia o montante em bancors necessário para compras externas. Keynes evidentemente "buscava impedir a supremacia do dólar como moeda internacional e a possibilidade de que a criação desta ficasse subordinada, como finalmente ocorreu, às políticas internas e à projeção mundial dos Estados Unidos", e neste caso, na medida em que nenhuma nação teria poder de criar bancors, somente tendo acesso a divisas a partir de sua participação no comércio exterior, Keynes "pretendia favorecer claramente aquelas economias que - como a Grã-Bretanha - apresentavam um elevado coeficiente de abertura comercial externa", o que faria com que "o poder de voto da área esterlina e européia (...) [fosse] muito mais alto e decisivo que o dos Estados Unidos" (LICHTENSZTEJN e BAER, 1987: 30).

Mas as circunstâncias históricas não permitiriam grandes ganhos de terreno de Keynes e dos britânicos sobre White e o Tesouro Americano. As negociações na Conferência de Bretton Woods deram então origem ao novo padrão-ouro (agora tendo o dólar como moeda plenamente conversível) e às instituições internacionais que teriam por função resguardar o funcionamento do padrão monetário. O Fundo Monetário Internacional e o Banco Mundial surgiram justamente com a perspectiva de garantirem "uma trajetória relativamente equilibrada das balanças de pagamentos e estável quanto às relações cambiais" (LICHTENSZTEJN e BAER, 1987: 31). O FMI, dispondo de recursos financeiros, bem como capacidade de monitoração e intervenção, "tinha condições de penalizar os governos responsáveis por políticas que desestabilizassem o sistema internacional e oferecer compensações aos países que fossem afetados negativamente" (EICHENGREEN, 2000: 132). Os signatários da Conferência de Bretton Woods aceitavam a ação do Fundo na imposição de um conceito de convertibilidade obrigatória entre moedas, derivado do Plano White, muito mais rígido do que aquele apresentado por Keynes, que "centrava a questão nos procedimentos de compensação e aconselhava 
limites aos processos de convertibilidade das moedas em ouro" (LICHTENSZTEJN e BAER, 1987: 31).

Além disso, Keynes propôs que os mecanismos de ajuste no balanço de pagamentos a serem conduzidos pelo Fundo Monetário Internacional fossem impostos não somente aos países deficitários, mas também aos países credores e superavitários. Essa era uma postura evidentemente favorável aos países endividados durante a guerra, como era o caso inglês. Formalmente, esta fora uma das importantes vitórias de Keynes na Conferência, na medida em que os Acordos do Fundo foram aprovados prevendo sanções para países superavitários com "moeda escassa" no mercado mundial. As sanções, contudo, nunca chegariam a ser aplicadas na prática. Isto expressava, na prática, o fato de o funcionamento do FMI e do Banco Mundial estar sendo estruturado em Bretton Woods sob evidente poder imperial norte-americano, baseado em três grandes premissas: a) O Banco Mundial não seria uma peça importante do sistema, ao contrário do FMI; b) o Reino Unido não discutiria a autoridade dos EUA sobre o funcionamento do Banco e do Fundo; c) reconhecer-se-ia a influência do mercado financeiro americano na provisão de fundos, e como conseqüência, a ingerência dos banqueiros americanos na direção do sistema (LICHTENSZTEJN e BAER, 1987: 33).

Assim, os Acordos previam o estabelecimento do Fundo Monetário Internacional, para promover consulta e colaboração quanto a problemas monetários internacionais, pôr em execução os Artigos e emprestar aos países membros com balança de pagamentos deficitária. Atribuía-se ao Fundo o poder de exigir de cada membro a manutenção das paridades cambiais em suas moedas dentro de marcos previamente acordados, e fiscalizar para que os países assumissem o compromisso de amortizar os saldos de suas moedas adquiridas por outros membros; amortização que deveria acontecer em ouro ou na moeda do país que solicitasse a conversão de seus saldos. Ainda, o FMI deveria ser administrado de modo a estar sempre em condições de atuar como emprestador de última instância, fornecendo recursos angariados a partir das quotas fornecidas por cada país membro. 
ATUAÇÃO DA DELEGAÇÃO BRASILEIRA NA FORMULAÇÃO...

Empréstimos com a finalidade de financiar emigração de capitais seriam proibidos, o que abria uma exceção na orientação liberal norte-americana no que tange os fluxos monetários e de mercadorias. Neste caso, a ressalva contra os fluxos especulativos era justificada pelo fato de que "Taxas de câmbio fixas, mas ajustáveis, [seriam] factíveis somente porque os controles de capitais protegiam os países que buscavam defender suas moedas contra os fluxos de capital desestabilizadores" (EICHENGREEN, 2000: 132).

Outra concessão, esta meramente formal, feita pelos norteamericanos, seria a introdução da idéia de "moeda escassa" como um elemento que configuraria "desobediência" de um player às regras do jogo de Bretton Woods. Ainda que a idéia fosse contrária "à concepção inicial de White de um mundo livre de controles sobre os fluxos comerciais e financeiros" (EICHENGREEN, 2000: 137), os termos do Acordo previam que se uma moeda de um país se tornasse "escassa" (ou seja, este país passasse a exportar mais do que importar, restringindo a circulação de sua moeda no mundo em função de mais entradas que saídas), o FMI poderia, em tese, autorizar que os demais países tomassem medidas cambiais discriminatórias, que envolviam inclusive controles cambiais sobre importações e outras compras em conta corrente (LICHTENSZTEJN e BAER, 1987: 32). Tal foi o alcance desta concessão: "como Keynes previra, a cláusula quanto a escassez de moeda do Fundo jamais [seria] invocada" (SOLOMON, 1979: 27).

\section{As Conferências de Washington e de Atlantic City: o Brasil entre dois Planos}

A partir de que percepções e com que posicionamentos definiu a delegação brasileira a participação neste longo processo de edificação das instituições fundamentais do chamado "Sistema Bretton Woods"? Como dito, os planos a partir dos quais moldou-se o sistema econômico internacional do pós-guerra nasceram com base em estudos de grupos técnicos 
norte-americanos e ingleses. Neste sentido, a formulação dos parâmetros da "nova ordem" parte de uma iniciativa bilateral. Mas entre a elaboração dos esboços dos Planos White e Keynes, ainda em 1942, e a Conferência de Bretton Woods, foram realizadas rodadas diplomáticas que submeteram as duas propostas à apreciação de técnicos de um grupo seleto de países; consistiram estas "rodadas" em espaços diplomáticos de ajuste, não de formulação, de modo que as alternativas postas sobre a mesa eram aquelas decididas por americanos e britânicos, cabendo às delegações presentes a estes encontros a proposição de mudanças pontuais.

Os principais encontros que antecederam o grande meeting em New Hampshire - a reunião de Washington de 15 de maio a 17 de junho de 1943, e de Atlantic City, entre 26 e 30 de junho de 1944 - contaram com a participação de Austrália, Bélgica, Brasil, Canadá, Chile, Cuba, Tchecoslováquia, Índia, México, Holanda, Filipinas e do Comitê Francês de Libertação Nacional, para além dos Estados Unidos e Reino Unido. O Brasil foi representado por Otávio Gouvea de Bulhões, na ocasião Chefe da Seção de Estudos Econômicos e Financeiros do Ministério da Fazenda e assessor técnico da Comissão de Mobilização Econômica desde janeiro de 1943. Já em Bretton Woods, a comitiva brasileira foi presidida pelo Ministro da Fazenda Arthur da Souza Costa, e teve como delegados Francisco Alves dos Santos Filho (Diretor da Carteira Cambial do Banco do Brasil), Valentim Bouças (da Comissão de Controle dos Acordos de Washington e do Conselho Técnico de Economia e Finanças), o decano das ciências econômicas no Brasil Eugênio Gudin (igualmente do Conselho Técnico de Economia e Finanças e da Comissão de Planejamento Econômico), Vitor Azevedo Bastian (Diretor do Banco da Província do Rio Grande do Sul) e Otávio Gouvea de Bulhões. Além destes, ocupou o cargo de secretário-geral da delegação Aguinaldo Boultreau Fragoso (Assistente do Ministro das Relações Exteriores Oswaldo Aranha), e o cargo de secretário Roberto de Oliveira Campos (na ocasião, segundo secretário da Embaixada do Brasil em Washington), Zeuxis Ferreira Neves (Assistente Técnico do 
Conselheiro Comercial da Embaixada do Brasil em Washington), Charles Freligh (membro da mesma embaixada), Santiago Fernandes (do Banco do Brasil S.A.), R.R. Vieira (da Delegação do Tesouro Brasileiro em Nova York) e Daniel Maximo Martins (SC.1944.05.08.mf.dg - II.13, 1944: 01).

Os encontros de Washington tiveram por finalidade permitir às nações convidadas a elaboração de considerações aos planos técnicos elaborados por norte-americanos e britânicos em 1942, conhecidos respectivamente como "International Stabilization Fund" e "Proposal for an International Clearing Union", comumente conhecidos como Plano White e Plano Keynes, respectivamente. Nas reunióes de Washington, após a discussão dos dois projetos, aprovou-se a Joint Statement consolidada por técnicos americanos, ingleses e soviéticos, que propunha a criação das instituições internacionais pensadas por Dexter White - o Fundo Monetário Internacional e o Banco Mundial. Aprovado o texto final das reuniões de Washington, F.D. Roosevelt prontificou-se em tornar pública a convocação para a Conferência Monetária e Financeira das Nações Unidas, para 1 a 23 de julho de 1944. Contudo, na medida em que a Joint Statement tratava do problema monetário ainda em linhas muito genéricas, e não tendo sido possível obter consenso a respeito de todos os seus dispositivos - em especial da parte dos defensores do Plano Keynes -, o Departamento de Estado norte-americano representado por Cordell Hull decidiu convocar uma reunião preliminar de modo a evitar que fossem levadas para Bretton Woods questões com arestas demasiado evidentes, o que poria em risco o caráter de congraçamento e legitimação da Conferência. A partir desta preocupação a reunião de Atlantic City foi convocada dias antes de serem iniciados os trabalhos em New Hampshire, e nela compareceram praticamente todos os delegados presentes nas reuniões de Washington. Os dispositivos da Joint Statement foram submetidos a uma nova redação, tendo sido discutidas várias expressões técnicas utilizadas e que geravam polêmica, tais como "moedas conversíveis em ouro", o conceito de "conta corrente no balanço de pagamentos", "transferências de 
capital", entre outros. Assim, são os resultados de Atlantic City que, compilados, foram apresentados em Bretton Woods.

Desde as reuniões de Washington de maio-junho de 1943 o Brasil se pronunciara em favor da criação do Fundo Monetário Internacional e da pertinência da junção dos Planos Keynes e White, considerados complementares em aspectos particulares. Preocupava Otávio Gouvea de Bulhões o fato de haver na ocasião, tanto nos Estados Unidos quanto na Inglaterra, "correntes contrárias à instituição de um instituto internacional com o fim de manter a estabilidade das moedas" (SC.1944.05.08.mf.dg - II.13, 1944: 11) ${ }^{1}$, correntes identificadas aos circuitos financeiros conservadores, que advogavam em favor da simples restauração do padrão-ouro e da adesão a uma moeda-chave (da mesma forma que no padrão libra-ouro) como medida suficiente para a estabilidade internacional (LICHTENSZTEJN e BAER, 1987: 26). Estes setores, segundo Bulhões, alegavam que a política econômica interna de cada país seria o único elemento pelo qual responderia a estabilidade monetária mundial, e neste caso, o máximo que se poderia exigir nas conferências internacionais pela reconstrução do sistema financeiro seria "uma conjugação de atividades entre os Bancos Centrais" (SC.1944.05.08.mf.dg - II.13, 1944: 12).

Manuscritos de trabalho depositados no arquivo pessoal de Arthur Souza Costa no CPDOC demonstram igualmente inquietação dos brasileiros acerca da oposição ao multilateralismo nos Estados Unidos: "É óbvio que o sucesso do plano dependerá de não se envolverem os países membros em aventuras inflacionárias e de que façam sérios esforços para corrigir a sua estrutura econômica", e com base nisto, pareceria insuficiente a conclusão do New York Times que afirmaria, a respeito das discussões, que "se a estabilidade interna existe, o plano é desnecessário. Se não existe, é inútil" (SC.1944.05.08.mf.dg - II.23, 1944). Decerto a imprensa novaiorquina, juntamente com os grupos financeiros privados norteamericanos, apareciam aos olhos da delegação brasileira como opositores ferrenhos da criação de instituições multilaterais para a gestão do sistema econômico internacional. Dizia Souza Costa, 
ATUAÇÃO DA DELEGAÇÃO BRASILEIRA NA FORMULAÇÃO...

em telegrama confidencial ao presidente Getúlio Vargas no dia 3 de julho de 1944 que "Apesar da oposição visível dos meios da Wallstreet, nota-se maior confiança, parecendo que tanto os ingleses como os americanos estão dispostos a chegar a uma conclusão positiva". Em 10 de julho, Souza Costa voltava a alertar Vargas a respeito do fato de que "o ambiente da Wallstreet é muito contrário à conferência", e em 14 de julho afirmara que "A imprensa de Nova Iorque continua procurando sabotar a possibilidade de chegar a um acordo" (GV.c.1944.07.01/2 2, 1944). Tudo isto se deveria ao fato de que

em matéria de cooperação internacional, a opinião publica nos Estados Unidos é uma das mais céticas. Muito embora reconheça o erro das tendências isolacionistas, mantém certas reservas quanto à concessão de créditos pelos enormes prejuízos sofridos na Europa, depois de 1920 (SC.1944.05.08.mf.dg - II-13, 1944: 19).

Assim, para Souza Costa, haveria "dispositivos de garantias que [são próprios] do Fundo e que os financistas ortodoxos querem ignorar", e que neste caso entender que a "solução do problema está na volta pura e simples ao padrão ouro internacional" com seus "corretivos sistemáticos", de acordo com a tese dos "Professores Kemmeren e Spahr e do Sr. Gents, vice-presidente do Guarantee Trust de Nova Iorque" (SC.1944.05.08.mf.dg - II-23), seria inapropriado. Segundo Bulhões,

Esse ponto de vista merece ser combatido. O Brasil, dentro das possibilidades de seus esforços, deve apoiar integralmente a bandeira lançada por esse grupo de técnicos americanos e ingleses, que desejam criar uma organização internacional de estabilidade monetária (SC.1944.05.08.mf.dg - II-13, 1944: 11-12).

Em nenhum momento a delegação brasileira pronunciou-se em favor de qualquer dos planos isoladamente, ainda que Eugenio Gudin tenha admitido posteriormente que se inclinava "pelo de Keynes, porque era mais simples, mais atraente" (E16, 
1979: 129). Isto contudo não preveniu Souza Costa de adotar o posicionamento presente na proposta keynesiana para estabelecer crítica ao retorno do padrão-ouro, visto como um "sistema rígido de paridades [que] subordina a economia interna à taxa cambial" (SC.1944.05.08.mf.dg - II-13, 1944: 16). Justificava sua preocupação recorrendo à interpretação corrente acerca dos fatos que levaram à década de crise de 1930 e à Segunda Guerra Mundial:

O caos monetário invadira o mundo, deixando emergir movimentos de nacionalismo extremo ou de isolacionismo quase que completo. Voltados para o passado, os homens de boa vontade acreditavam melhorar a vida econômica, fazendo reviver fórmulas antigas - separadamente em cada país. Iludidos com essa idéia, aparentemente de execução mais fácil, persistiam em não tentar a solução de se congregarem a fim de estabelecerem uma instituição internacional e, desse modo, esses conservadores muito contribuíram para que o extremismo tomasse conta e alcançasse o apogeu no decênio 1931-1940, que é o período mais triste do egoísmo na vida das nações (SC.1944.05.08.mf.dg - II-13, 1944: 16).

Assim, a delegação brasileira insistiu na necessidade da construção de mecanismos institucionais multilaterais de modo a evitar que "uma evasão de ouro [provocasse] uma estrutura de preços violentamente reajustados (...), com deflação e desemprego". Segundo Bulhões,

torna-se indispensável criar organizações internacionais onde se coordene a política monetária relativamente ao comercio mundial e se orientem as correntes de capital de uns para outros países. Não se poderá contar com um mundo melhor sem alvitrar uma instituição permanente de reequilíbrio dos balanços de pagamento por meio de uma cooperação sistematizada entre as nações (SC.1944.05.08.mf.dg - II-13, 1944: 16).

Afirmava Souza Costa em seus apontamentos elaborados durante os trabalhos no Mount Washington Hotel, que "a livre 
circulação de ouro e capitais que cria a interdependência e a instabilidade no mercado de juros constitui excelente mecanismo para espalhar internacionalmente a inflação e a deflação" (SC.1944.05.08.mf.dg - II-23, 1944). Mas o maior risco que observava, em decorrência do eventual fracasso da Conferência de Bretton Woods seria o de retorno a um sistema, vigente até os anos 1930, no qual não se pudesse lançar mão do principal "dogma intervencionista" legado pelo New Deal, ou seja, a gestão estatal dos fluxos de capital, e por conseqüência, dos juros e do câmbio (NAU, 1992: 96). Como anotara, "A subordinação dos fatores internos aos fatores internacionais submete a moeda e o crédito a influências externas e torna impossível a orientação governamental da economia, necessária para evitar as depressões", que ocorreriam inevitavelmente visto que "O mecanismo de auto-regulação da balança comercial de pagamentos somente pode funcionar em condições especiais, incompatíveis com a presente rigidez das estruturas de preços e salários" (SC.1944.05.08.mf.dg - II-23, 1944).

Em Washington e Atlantic City, a representação brasileira buscou atuar de modo que os termos encaminhados ao debate em Bretton Woods fossem tais que reunissem aquilo que consideravam de mais relevante tanto no Plano White quanto no Plano Keynes. No geral, Bulhões acreditava que o pilares fundamentais da proposta "International Stabilization Fund", encaminhada pela representação norte-americana, seriam suficientes como base para a proposta final, visto que garantiam mecanismos de atuação sobre o sistema econômico internacional e de vigilância institucional sobre as políticas econômicas nacionais.

(...) o plano White estabelece a garantia das reservas em correspondência com a provável utilização de recursos do Fundo, além de relacionar a aquiescência de um país em seguir uma política monetária sã à circunstância de recorrer mais freqüentemente ao Fundo (SC.1944.05.08.mf.dg - II-13, 1944: 1112). 
Explicava Souza Costa à Associação Comercial de São Paulo em maio de 1944 que justamente neste aspecto, o Plano White traria "fundamento mais lógico e inspirador de maior confiança" (SC.Costa, S.pi.1942.04.30, 1944: 7), na medida em que estabelecia que o direito de cada nação de acessar os recursos financeiros do Fundo Monetário Internacional estivesse condicionado à subscrição de determinada cota junto ao Fundo, calculada "em função do ouro que possuir [o país], da extensão normal de suas flutuações no balanço de pagamentos e ainda da renda nacional" (SC.Costa, S.pi.1942.04.30, 1944: 12). A subscrição das cotas junto ao Fundo funcionaria, então, como uma operação de securitização dos balanços de pagamentos.

Essa reserva constitui uma espécie de 'prêmio' para o seguro contra os riscos de flutuações no balanço de pagamentos. Em Washington e Atlantic City, ao discutir com os peritos americanos e ingleses, manifestaram-se nossos peritos, por esse motivo, pela conveniência da presença das reservas (SC.Costa, S.pi.1942.04.30, 1944: 7-8).

Assim, entendia a representação brasileira que a desproporção entre o valor das cotas subscritas junto ao Fundo Monetário Internacional e as necessidades financeiras diante de uma eventual crise cambial não deveria funcionar como fator de restrição à capacidade de um país equilibrar suas contas externas por meio da ajuda internacional, visto que "a cota não [consistiria] no simples reconhecimento do montante de débito que o país pode dispor. Essas reservas não precisam ser de vulto, uma vez que admite a possibilidade de conceder créditos de duzentos por cento o valor do depósito em ouro" (SC.Costa, S.pi.1942.04.30, 1944: 12). A representação brasileira temia que o percentual de crédito estabelecido tivesse um eventual impacto "expansionista", mas decerto era visto como uma opção mais segura por ser mais conservadora. "O Plano Keynes foi considerado desde seu lançamento como expansionista em demasia. No Plano White, exigindo-se o depósito de reservas prévias, a expansão fica a estas subordinada" (SC.Costa, 
ATUAÇÃO DA DELEGAÇÃO BRASILEIRA NA FORMULAÇÃO...

S.pi.1942.04.30, 1944: 12).

Mesmo considerado em linhas gerais mais seguro, o Plano White careceria de caráter inovativo segundo a concepção da delegação brasileira nos acordos pré-Bretton Woods, representando a aplicação de princípios já conhecidos, acrescidos da dimensão institucional conferida pela proposição da criação do Fundo Monetário Internacional e do Banco de Reconstrução e Desenvolvimento. Já "o plano inglês é extremamente engenhoso em seu funcionamento, sendo, nesse ponto superior ao plano americano", segundo Bulhões (SC.1944.05.08.mf.dg - II-13, 1944: 11). Admirava a Souza Costa a idéia de que Keynes tivesse aplicado às transações internacionais "os mesmos princípios que regem as operações bancárias", na medida em que o novo meio de troca internacional não estaria baseado em uma moeda nacional, e sim, em uma moeda escritural. Os países deveriam assim estar "dispostos a aceitar o pagamento das importâncias que lhe forem devidas, não em moeda, mas em simples lançamento nos livros de uma instituição de crédito". Tal seria o papel da International Clearing Union (União Internacional de Compensações): "uma instituição intermediária entre o país com saldo favorável e o deficitário" (SC.Costa, S.pi.1942.04.30, 1944: 7-8). Gudin também admirara o plano britânico, e insistia em defini-lo a partir da imagem elaborada didaticamente pelo próprio Lord Keynes: a Clearing Union seria "uma ilha no meio do oceano, onde haveria um guarda-livros"; as várias nações do mundo "teriam seus débitos e créditos ali", e nela "haveria uma moeda internacional chamada bancor, e a contabilidade internacional seria baseada nessa moeda" (E16, 1979: 128). Dentre as virtudes da criação da International Clearing Union estaria, para Souza Costa, o fato de nas trocas internacionais somente serem utilizadas reservas caso verificada a necessidade real de entrega de cambiais para o restabelecimento do balanço de pagamentos do país vendedor. "Em vez de se recorrer a reservas com o fim de antecipar recursos para um débito, somente se apela para as reservas depois de constituído o débito". Assim, "participando um país de entendimentos 
internacionais, nos quais se exige a entrega de certa parte das reservas, tal país não dilapidará suas reservas (...)". Caso a proposta da Clearing Union fosse vitoriosa, insistia o Brasil na indispensabilidade da pronta garantia da entrega de cambiais caso solicitada pela parte vendedora, "conservando, assim, a (...) característica garantidora de recursos" da União de Compensações (SC.Costa, S.pi.1942.04.30, 1944: 7).

Assim, no Plano Keynes, um dos principais problemas identificados pela delegação brasileira no Plano White estaria eliminado. "No plano inglês, não há possibilidade de escassez de cambiais, relativamente a uma certa moeda. $O$ limite de suprimento, ou melhor, o limite de crédito, corresponde ao montante total dos limites dos débitos" (SC.1944.05.08.mf.dg II-13, 1944: 11). Exemplifica Souza Costa, "se os países da América do Sul dispusessem de um crédito de 500 milhões de dólares, poderiam comprar 500 milhões de dólares de mercadorias em determinado país, quando aí lhes conviesse efetuar compras" (SC.Costa, S.pi.1942.04.30, 1944: 13). O país vendedor teria que receber $o$ valor da venda onde os compradores tivessem saldo disponível, e caso este não existisse, deveria receber $\mathrm{o}$ valor da venda em produtos importados do país comprador. Assim, segundo Gudin, uma das originalidades do Plano Keynes estaria no fato de que "O país credor era obrigado a ajudar o devedor, como um dos meios de restabelecimento do equilíbrio" (E16, 1979: 128). Neste sistema, não faltariam divisas no mercado internacional, fato que o Plano White não poderia assegurar, visto que "o compromisso do país, de manter a sua moeda estável, para atender as solicitações de procura, não vai além do valor da sua cota [no Fundo Monetário Internacional]" (SC.Costa, S.pi.1942.04.30, 1944: 12). A partir da análise do Plano Keynes, a delegação brasileira elegeu a "moeda escassa" como problema-chave, insistindo na idéia de que o Plano White, apesar de estruturalmente mais sólido, caso fosse posto em prática sem ressalvas, poderia contribuir para novas perturbações no comércio internacional. "Um país que exporta em grande volume e importa em escala diminuta, sem oferecer compensações no balanço de capitais, faz com que a sua moeda 
se torne escassa no mercado mundial. A grande afluência de ouro para os Estados Unidos, em certos períodos da década de 1930 a 1939, é, em parte, atribuível à escassez do dólar", e desta forma no "Plano Keynes resolve-se esse problema de escassez de moedas, eis que o limite de suprimento, ou melhor, o limite de crédito, corresponde ao montante total dos limites de débitos" (SC.Costa, S.pi.1942.04.30, 1944: 9-10).

Apesar de considerado uma criativa produção do pensamento econômico, e de ter reconhecida a relevância do problema da escassez de moedas, o Plano Keynes seria rejeitado pela delegação brasileira, em função de seu caráter "expansionista" e da prioridade dada ao pleno emprego. Como afirmou Gudin, "O mundo ainda não tinha maturidade para o Plano Keynes" e esse foi "o argumento alegado para que não se aceitasse [a proposta britânica]" (E16, 1979: 129). De fato, para Keynes, escapar da "tirania do ouro" não seria suficiente. "[He] also wanted to prevent the reestablishment of any common international monetary standard that would again limit the autonomy of national governments to determine their own monetary policies" (MCKINNON, 1993: 12). Assim, apesar de ver o plano britânico com simpatia, e elogiá-lo como uma importante peça de raciocínio econômico, a delegação brasileira acreditava que sua excessiva ousadia não era segura para o momento, embora alguns de seus insights pudessem ser usados para "provocar" a delegação norte-americana no sentido de alterações necessárias no Plano White.

Visto terem sido as relações cambiais no Plano Keynes unicamente vinculadas à participação da nação no comércio internacional, "as possibilidades do débito [seriam] muito amplas", de modo que "o montante [tornar-se-ia] inaceitável". Ainda que na proposta de criação da International Clearing Union medidas restritivas fossem previstas, tais como o impedimento do uso total do crédito para compras, e a exigência, para nações compradoras, de apresentação de garantias em ouro e cambiais sempre que metade do limite de seu crédito internacional fosse utilizado para importações (SC.Costa, S.pi.1942.04.30, 1944: 10), o plano, tal como 
apresentado, fora considerado arriscado. Mesmo, como sugeria Bulhões, que reduzisse "a soma do débito aos limites das flutuações, garantida ainda com reservas adequadas (...)", "a garantia máxima [deveria] ser assegurada, da mesma forma como se garante o pagamento de todos os depósitos ou todos os seguros" (SC.1944.05.08.mf.dg - II-13, 1944: 11).

Preocupava Souza Costa o fato de a postura britânica de defesa do full employment aparecer naquele momento como um fato "mais político do que econômico", e em suas anotações de trabalho reproduzia a preocupação evidenciada por Keynes quando afirmara que "Nenhum governo na Grã-Bretanha sobreviverá por mais de seis meses com 'desemprego e depressão' mas poderá sobreviver a vários orçamentos desequilibrados". Assim, considerando que o Reino Unido havia entrado "definitivamente na economia dirigida do após-guerra", demonstrava que a Coroa "não aceitaria de modo algum a camisa de força do padrão-ouro", e acreditava que a postura britânica não iria "além do flexible link with [the] gold" (SC.1944.05.08.mf.dg - II-23, 1944), fato este que certamente era visto como positivo pela delegação brasileira - dada a sua postura contrária à recriação do gold standard aos moldes oitocentistas - mas que poderia certamente dificultar o objetivo que tinha em comum com a delegação norte-americana, de defesa incondicional da estabilidade.

Assim, entendendo que o problema da moeda escassa devia ser combatido, e que a maior segurança possível às transações comerciais e aos balanços de pagamentos devia ser oferecida, a delegação brasileira concluíra sua participação nas reuniões de Washington com a sugestão de que "os planos americano e inglês devem ser reunidos". Afirma Bulhões que

a conjugação do limite das contas, segundo as flutuações no comércio internacional, com a garantia de reservas flexíveis do plano White e o plano Keynes, representa um magnífico aperfeiçoamento sobre cada um dos planos em separado. $O$ esforço do Brasil, no sentido de conseguir essa reunião, será de grande alcance (SC.1944.05.08.mf.dg - II-13, 1944: 12). 
ATUAÇÃO DA DELEGAÇÃO BRASILEIRA NA FORMULAÇÃO...

Então, das análises e discussões em Washington foi elaborada a Joint Statement (Declaração Conjunta) sobre o Fundo Monetário Internacional, publicada em 22 de abril de 1944. Como afirmou Solomon, tratava-se de um documento conciliatório, que em grande medida modificava o Plano White a partir de críticas esboçadas através da proposta de criação da Clearing Union (SOLOMON, 1979: 23), o que significava dizer que o posicionamento brasileiro no que tange a união dos dois planos fora aspiração também de outras delegações nas discussões prévias à Bretton Woods. Tal fato não escondia, contudo, a vitória da proposta americana, tal como demonstrara Gudin: "Ali trabalhamos, tomando por base este Plano White" (E16, 1979: 127). Na visão de Souza Costa, a Joint Statement evidenciava-se de fato como um documento conciliatório na medida em que nela "não figurou mais a idéia de estabilização constante do plano primitivo americano [dada a flexibilidade admitida na taxa de câmbio, da qual trataremos depois], tendo sido introduzidas também modificações radicais contra a escassez de moeda" (SC.1944.05.08.mf.dg - II-13, 1944: 12) por meio do "reconhecimento da possibilidade de restrições cambiais contra o país credor que não se dispuser a reduzir o valor de seu crédito, através do aumento de suas importações" (SC.Costa, S.pi.1942.04.30, 1944: 14). Além disso, foram mantidas as cotas de participação no Fundo, mas em proporções menores que "as do primitivo plano", o que reduzia o "inconveniente da possibilidade de expansões perigosas, que se poderiam recear no Plano Keynes" (SC.1944.05.08.mf.dg - II-13, 1944: 12).

Ainda que Souza Costa afirme que os acordos que levaram à elaboração da Joint Statement tenham promovido uma "conciliação de técnica e interesse político" (SC.1944.05.08.mf.dg - II-13, 1944: 13), este último permanecia arredio ao espírito de congraçamento. Ficaram sem definição questões cruciais como a fixação das paridades, as bases para o cálculo das cotas e o estabelecimento das regras para a direção do Fundo Monetário Internacional. Após definidos os princípios básicos, restavam definições de caráter operacional que 
inevitavelmente questionariam a dimensão conciliatória do processo, na medida em que era na "ponta do iceberg" - ou seja, nas definições operacionais - que se localizava linha de tensão entre os interesses políticos em jogo. Em Bretton Woods, as negociações corriam grande risco político de fracassarem caso as definições pendentes não fossem previamente definidas, se os vencedores não fossem reconhecidos e os derrotados não estivessem resignados; considerando a maior pluralidade de vozes convocadas a New Hampshire - quarenta e quatro delegações - e a insistente oposição por parte da Wallstreet e da imprensa, a pauta a ser apresentada em Bretton Woods deveria ser plenamente consensual entre o Reino Unido e os Estados Unidos, e contar com a aceitação por parte dos players menores convocados para as negociações prévias. Assim, para dirimir estes problemas, F.D. Roosevelt e o Secretário de Estado Cordell Hull convocaram para os últimos dias de junho de 1944 mais uma prévia em Atlantic City, para a qual foram convocadas as mesmas delegações presentes em Washington. Foi Otávio Gouvea de Bulhões que partiu para os Estados Unidos dias antes do restante da delegação brasileira, de modo a tomar parte nesta rodada de negociações. Os Termos do Acordo que criaram o Fundo Monetário Internacional e o Banco de Reconstrução e Desenvolvimento foram firmados ali.

\section{Impressões e Reações da Delegação Brasileira em Bretton Woods aos resultados das conferências preliminares de Washington e Atlantic City}

Qual foi o legado das negociações de Atlantic City e o que foi efetivamente acolhido em Bretton Woods? Em primeiro lugar, Souza Costa entende que o principal resultado de todo o processo, e que foi referendado em plenitude pelas quarenta e quatro nações, foram os princípios gerais do Fundo Monetário Internacional, que é aprovado como sendo em última análise "uma instituição de seguros contra as flutuações no balanço de pagamentos", a partir da qual "poderemos minorar os efeitos 
ATUAÇÃO DA DELEGAÇÃO BRASILEIRA NA FORMULAÇÃO...

maléficos dos desequilíbrios econômicos do comércio internacional, em benefício de todos". A respeito das cotas de participação, idéia apresentada no Plano White e flexibilizada na Joint Statement, pactua-se que "A parte da cota em moeda nacional representa a contribuição de cada país para o uso de sua moeda pelos demais países", "a parte ouro representa a garantia da soma de moeda nacional excedente que os países entregam ao Fundo para obtenção de moeda de outro país", e, de modo a evitar o uso "irresponsável" dos recursos internacionais, "os países são obrigados a readquirir esse excedente de sua moeda, dentro de prazos razoáveis" (SC.1944.05.08.mf.dg - II-13, 1944: 13). A delegação brasileira não apresenta restrições ao fato do dólar assumir o poder de moeda internacional, desde que o padrão ouro-dólar não funcione sem as instituições multilaterais propostas no Plano White. Gudin em nenhum momento rejeitou o padrão-dólar, afirmando ainda que, em determinados momentos, "quem dava valor ao ouro era o dólar e não vice-versa" (E16, 1979: 130).

A delegação brasileira entendeu que o resultado da negociação sobre as cotas do Fundo Monetário realizadas em Bretton Woods com base na proposta prévia de Atlantic City foi bastante favorável aos players menores. A princípio a Conferência teria tentado seguir um critério que chamou de "matemático", calcado em uma fórmula empírica que permitiria "aquilatar o poder econômico de cada país", na qual fixava-se como índice para determinação das cotas a serem subscritas " $2 \%$ da renda nacional; mais $5 \%$ das reservas-ouro e cambiais em moeda livre; mais 10\% do valor médio da importação de 1934 a 1938; mais $10 \%$ do valor da avaliação máxima da exportação de 1934 a 1938" (SC.pi.Costa.S.1944.09.19, 1944: 35-36). A proposta causara certo desconforto para o Brasil no que diz respeito à avaliação máxima das exportações "porque a cota de $25 \%$ para o Brasil seria pequena, em face das oscilações que temos observado nas nossas estatísticas, as quais, por vezes, excedem de 30\%". Este entendimento levou a delegação a pleitear a flexibilização dos 25\% para 33\% "o que cobre perfeitamente todas as variações cíclicas que o Brasil tem tido" 
(SC.pi.Costa.S.1944.09.19, 1944: 36).

Contudo, não só o Brasil demonstrava descontentamento em relação ao critério "matemático" de fixação das cotas de participação no FMI. A questão tornou-se ponto de tensão entre as delegações, visto que a determinação "objetiva" do quantum de recursos com os quais cada país deveria integrar o Fundo limitava "objetivamente" o montante de ajuda que poderiam receber. Como afirma Souza Costa, "[o critério "matemático"] não podia ser seguido, em absoluto, por motivos de ordem política. As grandes nações não se conformaram com tal critério" (SC.pi.Costa.S.1944.09.19, 1944: 37). Em telegrama confidencial de 10 de julho de 1944, endereçado ao presidente Getúlio Vargas, relatava o presidente da delegação brasileira que "todos os pontos relativos ao Fundo Monetário vêm sendo debatidos exaustivamente", e que "uma das maiores dificuldades é a distribuição de quotas-partes com que os países devem contribuir"; "cada um ou melhor cada grupo quer maior quota" na medida em que seu valor "é importante pelo aspecto econômico porque o limite de disponibilidade em crédito é função da quota e pelo lado político porque também o poder do voto na administração do fundo está em relação à quota parte". Assim, "apesar do espírito de colaboração que anima os trabalhos, sente-se o choque de vários grupos e as soluções para - caso são mais de caráter político do que técnico" (SC.1944.05.08.mf.dg - I-47, 1944). Após uma série de manobras políticas foram votadas as cotas de participação, tendo sido confirmada para o Brasil a elevação de US\$ 100 milhões para US\$ 150 milhões (lembrando que anteriormente fora estabelecida elevação do percentual de $25 \%$ para $33 \%$ sobre a avaliação máxima do desempenho das exportações), que segundo Souza Costa além de ser "suficiente para as nossas necessidades", estaria "além daquilo que inicialmente estabeleceu a Conferencia de Atlantic City", o que projetou o país como nação latino-americana de mais elevada participação no Fundo, seguido do México com US\$ 100 milhões (SC.pi.Costa.S.1944.09.19, 1944: 37). Este processo de fixação de cotas "um pouco à base dessa formula [matemática] e um pouco 
à base de combinações políticas", resultou em uma cota de US\$ 2750 milhões para os Estados Unidos, US\$ 1300 milhões para o Reino Unido, US\$ 1200 milhões para a União Soviética, US\$ 550 milhões para a China e US\$ 450 milhões para a França; "daí por diante" todos os países obtiveram valores "abaixo de US\$ 300 milhões" (SC.pi.Costa.S.1944.09.19, 1944: 37). A discussão não se pacificou imediatamente, tendo várias delegações considerado que a força dos norte-americanos e britânicos gerava alto grau de injustiça, fato que levara "o chefe da delegação americana [a fazer] um apelo patético no sentido de todos se conformarem". O apelo fora acatado por força das circunstâncias, mas não prevenira, como relata Souza Costa a Vargas, que votassem "com restrições a China, Índia, França, Austrália e outros menores que consideraram as quotas abaixo das que julgavam com direito" (SC.1944.05.08.mf.dg - I-57).

O protesto das delegações era evidente, abatendo o clima de congraçamento que deveria ser totalmente manifesto em Bretton Woods; afinal, para isso as negociações prévias haviam sido feitas com cuidado, de modo a dar à "rodada final" ares de consenso. Quanto às quotas, norte-americanos e britânicos pensavam que pouco havia a ser feito; a prioridade dos recursos do Fundo havia sido estabelecida. Mas restava o problema do poder de voto - relacionado, com sabemos, à cota-parte possuída por cada nação - e pactuar a configuração da chefia da instituição, definindo se deveria ser concentrada ou fragmentada num órgão colegiado. Se sabemos que se manifestava um clima de inquietação entre as delegações, e unirmos a esta informação a de que o critério de determinação do número de votos no Fundo acabara sendo relativamente desvinculado do volume das cotas subscritas, podemos seguramente sugerir que esta medida foi encaminhada no claro intuito de restabelecer a legitimidade dos acordos em processo de pactuação em Bretton Woods. E coube justamente ao Brasil a vice-presidência da Comissão de Direção (Steering Commitee), encarregada de definir a administração do Fundo. Os reflexões das decisões tomadas seriam amplos: "Nesse Comitê seriam objeto de discussões todas as questões de interesse político das nações 
envolvidas e dada a correspondência entre esses problemas no Fundo e na organização do Banco, é claro que a solução atribuída no Fundo, primeiramente discutido, serviria de base, automaticamente, para a consideração do mesmo problema na parte relativa ao Banco" (SC.1944.05.08.mf.dg - II-13, 1944: 33). As diferenças logo se manifestaram entre os major players (Estados Unidos - Reino Unido), que não se entenderam a respeito da melhor forma de administrar o fundo. Após negociações, arbitradas pela delegação brasileira, venceu a tese de que o Fundo seria administrado por um colegiado de doze membros.

\section{A delegação brasileira e as manobras para assegurar acesso à administração do Fundo Monetário Internacional}

Diante da vitória do princípio de que o FMI seria administrado de forma colegiada, a delegação cubana se prontificara em encaminhar duas propostas polêmicas: a primeira delas, o estabelecimento de um número de votos por nação, para além do número de cotas subscritas, e a eleição de dois membros latino-americanos para a diretoria do Fundo. Apoiada pelos Estados Unidos - o que sugere mais uma vez a busca de legitimidade para os acordos em elaboração, sem ampliar contudo o acesso destes países aos recursos financeiros do FMI -, a delegação cubana obtém vitória na segunda proposta, que foi prestigiada pela delegação brasileira "conquanto convencidos de que envolve, de certo modo, uma injustiça, mas, sob o ponto de vista político [ser] profundamente interessante" (SC.pi.Costa.S.1944.09.19, 1944: 38). Ficava definido então que cada país teria direito a 250 votos como nação, mais um número de votos proporcional à sua cota parte. Souza Costa entendia que "As nações pequenas, como o Paraguai, são favorecidas. O Paraguai tem apenas meio milhão e dispõe de 255 votos: 25 votos pelo capital e 250 como nação. Com um capital infinitamente pequeno tem, entretanto, um poder de voto maior" (SC.pi.Costa.S.1944.09.19, 1944: 39). A 
manobra foi aceita com reservas pelo Brasil, que lidou com a primeira proposta cubana ainda com maior cuidado.

Quanto à proposta de eleição de dois diretores latinoamericanos para a comissão executiva do Fundo, Bulhões afirma que "não podia deixar de ser vista com simpatia", o que, entretanto, não deveria impedir a delegação do Brasil de apontar os pontos fracos da mesma tese, centrados na idéia de que "uma instituição como a do Fundo é genuinamente internacional", e neste caso " os diretores não deveriam ser representantes de países ou regiões" (SC.1944.05.08.mf.dg - II-13,1944: 32). Assim, segundo Bulhões, seria desejável que os diretores fossem escolhidos não apenas pelos próprios países ou regiões da América Latina, mas por todas as nações membros do Fundo Monetário Internacional "o que permitira, em sua direção, um concurso mais amplo das correntes de opinião do mundo". Deste fato teria decorrido a "a atitude discreta que resolvemos [a delegação brasileira] manter na discussão do assunto" (SC.1944.05.08.mf.dg - II-13, 1944: 32).

A postura de fato marcada por discrição não significara, contudo, inação. As fontes diplomáticas oferecem indícios relevantes de que a delegação brasileira atuara atrás da cena de modo a ganhar espaço político a partir da proposta cubana, e que o Brasil negociava secretamente o estabelecimento da eleição dos dois representantes como prerrogativa exclusiva das nações latino-americanas, ao contrário do comportado internacionalismo alegado por Bulhões e Souza Costa, que supostamente motivara o posicionamento brasileiro na questão. Em um manuscrito em papel timbrado da "United Nations Monetary and Financial Conference", sem data ou assinatura, mas tendo como destinatário o ministro Souza Costa, um dos membros da delegação brasileira alertava o presidente da comitiva acerca dos seguinte problema:

"Uma coisa é assegurar dois lugares para pessoas da América Latina, e outra muito diversa é promover politiquice na América Latina. Não há o menor desdouro para a América Latina em que os dois representantes que os estatutos do Fundo lhe asseguram, 
sejam escolhidos pelo conjunto de todos os países como não é tampouco digno para que os representantes da América Latina sejam privados do direito de opinar e votar na escolha dos demais diretores do Fundo" (SC.1944.05.08.mf.dg.II-40, 1944: 12).

O interlocutor secreto defendia a pertinência do internacionalismo como fundamento na orientação da política da delegação: "O Fundo é, por excelência, uma instituição de caráter universal e quem for para sua direção com mentalidade regional nunca poderá ser um bom diretor". Assim, sugere a Souza Costa que "Na escolha das pessoas para dirigir o Fundo deveríamos pensar, antes de tudo, na capacidade dessas pessoas para o exercício do cargo", fato justificado não só por questões éticas, mas também pelo interesse econômico da nação: "Como acionistas do Fundo, nosso desejo é o de escolher bons diretores. $\mathrm{O}$ que se deve apenas exigir é que dentre os diretores hajam europeus, americanos e dois da América Latina". Ao interlocutor secreto, esta seria a única saída honrada e segura para o problema levantado pelos cubanos: "Politicamente não ficaremos mal perante os demais países da América Latina apoiando essa tese e melhor ainda nos apresentaremos diante das demais nações" (SC.1944.05.08.mf.dg.II-40, 1944: 1-2).

Entretanto, a partir do apoio dos Estados Unidos, tornou-se vitoriosa a tese da escolha dos diretores latino-americanos por eleição dos próprios países da América Latina, sem a colaboração de outras nações; tendo este "fato consumado" nas mãos, a delegação brasileira teria então, "dada a indiscutível situação do Brasil entre os países latino-americanos", pleiteado e obtido "disposições que praticamente lhe asseguram um lugar na Comissão Executiva" (SC.1944.05.08.mf.dg - II-13. 1944: 34). Fontes indicam que, por trás do fato, temos a ação da delegação brasileira e do ministro Souza Costa, que provavelmente ignorou as advertências do interlocutor secreto. Em um bilhete escrito em papel timbrado da Conferência, sem destinatário ou remetente, outro agente anônimo revela: "Venho de falar com 
ATUAÇÃO DA DELEGAÇÃO BRASILEIRA NA FORMULAÇÃO...

Miller. Levou ele nosso ponto de vista ao State Department que afinal compreendeu que se tratava de assunto delicado e que nós tínhamos razão". Tudo indica que o "ponto de vista" a que se refere é a tese da "eleição endógena", defendida como melhor opção tanto para o Brasil quanto para os Estados Unidos. E prossegue: "Receberam bem a 'fórmula Bouças' e a estão organizando para apresentar", o que sugere a participação efetiva de Valetim Bouças na manobra. Dando a entender que seria por demais óbvio que a delegação brasileira defendesse publicamente a idéia da "eleição endógena", afirma: "Declarei que o Brasil não deveria apresentá-la, competindo isso a outrem, preferível o próprio EEUU", fato que efetivamente veio a ocorrer. Preocupado com a possibilidade de a manobra funcionar, mas o Brasil acabar perdendo a indicação à vaga na Diretoria Executiva, o agente anônimo revela: "Expliquei, também, que não havíamos cuidado de votos e que seria interessante nos ajudarem, para obtermos o pouco que nos faltaria para obtermos os finais $2 / 3$. Parece que também concordaram". Possivelmente como forma de amenizar a oposição de países latino-americanos interessados na vaga, acrescenta que "havendo lugares na diretoria executiva do Banco [de Reconstrução e Desenvolvimento], isto serviria para negociações. Acharam interessante". E termina tranqüilizando a comitiva brasileira: "Parece, pois, que tudo esta melhor" (SC.1944.05.08.mf.dg.II-39, 1944). De fato as manobras correram bem para a delegação brasileira, visto que o almejado lugar na diretoria executiva foi alcançado.

\section{A posição da delegação brasileira quanto ao Joint Statement e aos Articles of Agreement do Fundo Monetário Internacional}

A delegação brasileira atuou firmemente em Bretton Woods para impedir que o princípio da fixação da taxa de câmbio pactuado em Atlantic City viesse a sofrer pressões no sentido da flexibilização durante o encontro de Bretton Woods. Persistia então a diplomacia brasileira 
no firme propósito de impedir que um dos pontos fundamentais da "Declaração Conjunta" fosse burlado por puros preconceitos de opinião pública, ou por exagerados receios quanto à possibilidade de manutenção das taxas de câmbio depois de fixadas pelos países participantes do Fundo (SC.1944.05.08.mf.dg - II-13, 1944: 37).

Diante da alegação de que as instituições internacionais de cooperação somente poderiam entrar em funcionamento após o ajustamento prévio das economias que iriam compô-las, de modo que fosse possível a estas nações "ganhar tempo" para efetuarem seus ajustes sem estarem condicionadas às pressões do Fundo Monetário Internacional, pronunciara-se o jovem Roberto Campos em relatório ao Ministro da Fazenda Souza Costa: "não se criaria o Fundo Internacional até que os diversos países pusessem a casa em ordem, quando precisamente eles necessitam de auxílio do Fundo para pôr a "casa em ordem'" (SC.1944.05.08.mf.dg - II-13, 1944: 30). Algumas delegações, com especial destaque para a australiana, tentaram modificar a redação da Joint Statement, de modo que a principal função prevista para o Fundo - "to promote exchange stability" - fosse substituída pela mais flexível "to secure orderly changes in exchange rates". As delegações do Canadá, Bélgica, Holanda e Grécia apoiaram proposta da delegação britânica no sentido de defenderem a primazia do full employment sobre a estabilidade cambial, propondo que o Fundo não oferecesse "objeções à alteração da taxa de câmbio, fosse qual fosse o limite, desde que essa alteração se tornasse necessária, para manter o alto nível de emprego num país, alem de outros casos de política social" (SC.1944.05.08.mf.dg - II-13, 1944: 37). Temos assim que "Rather than submitting to some international standard, exchange rates were to be sufficiently flexible to support nationally selected inflation and employment objectives" (McKINNON, 1993: 12). Ambas as proposições foram combatidas pelo Brasil, em conjunto com a delegação norte-americana, de modo que ficara estabelecida a liberdade de alterar as taxas de câmbio na 
proporção de $10 \%$ tal como figurava inicialmente na Joint Statement, guardadas as condicionalidades nela previstas.

Desde Atlantic City, Bulhões insistia na necessidade de definições mais precisas para alguns termos presentes na Joint Statement, e em Bretton Woods a delegação brasileira prosseguiu a campanha, especialmente no que diz respeito à definição do termo "transferências de capital" e "transações correntes no balanço de pagamentos". Estavam expressos nos objetivos do fundo que uma determinada nação só poderia contar com os recursos cambiais da instituição para atender ao "pagamento de importação de mercadorias e exportação de rendimentos, nestes incluídos apenas o capital previsto para amortizações" (SC.1944.05.08.mf.dg - II-13, 1944: 38), e desta forma, temia a delegação brasileira que as remessas feitas por imigrantes para o exterior pudessem ser enquadradas como migração de capitais fora do controle do Fundo. Após alguma negociação, teve sucesso a delegação brasileira em garantir ressalvas para este tipo de operação. Todavia, era considerado de interesse nacional pela delegação brasileira o controle do fluxo internacional de capitais.

É da própria natureza do Fundo não oferecer seus recursos para a transferência de capital. Conseqüentemente, é indispensável que os países exerçam uma supervisão geral das transações cambiais, baseada, principalmente, num amplo e rigoroso sistema estatístico das operações de câmbio (SC.1944.05.08.mf.dg - II-13, 1944: 31).

Em paralelo à defesa da fixação do câmbio, a delegação brasileira pleiteava a ampliação do limite anual de recursos disponíveis para os membros do Fundo, especialmente baseada na percepção de que nações exportadoras de bens primários corriam maiores riscos cambiais que os países exportadores de manufaturados, dadas as flutuações do mercado internacional de matérias-primas. Na visão de Bulhões, 
Alguns países europeus julgam satisfatórias [as] quotas que lhe foram atribuídas mas a verdade é que em se tratando [de] países industriais cujas exportações não estão sujeitas a flutuações violentas não seria de justiça atribuir-lhes maior porção em detrimento países agrícolas (SC 1944.05.08.mf.dg - I-58).

O texto da Joint Statement estabelecia uma waiver clause, na qual admitia-se a possibilidade do FMI isentar determinados países do cumprimento dos limites de recursos em circunstâncias especiais. Contudo, a cláusula era considerada muito vaga, o que levou algumas delegações a buscarem alterar não a waiver clause, mas os próprios limites de crédito em situações normais estabelecidos para a instituição. Os técnicos da Austrália vinham solicitando ampliação do limite anual de $25 \%$ da cota parte para 33\%, e a França propunha a modificação de todo o dispositivo de fixação das cotas, com base em um princípio de carry-over: seria facultado aos países obter quantias cada vez maiores a cada ano, em proporção ao número de anos subseqüentes que tivessem ficado sem solicitar recursos ao FMI. "Assim, um país poderia obter $50 \%$ no segundo ano, se não recorresse ao Fundo no primeiro; obteria $75 \%$ no terceiro, caso não recorresse nos dois anos anteriores, e assim por diante, até ficar com a faculdade de poder utilizar 200\% num único ano" (SC.1944.05.08.mf.dg - II-13, 1944: 34). Para a delegação brasileira, certamente a proposta francesa superava em interesse o plano de elevação dos $25 \%$ para $33 \%$, proposto em conjunto com os australianos; temia o Brasil, contudo, que o percentual estipulado pelos franceses fosse demasiado grande a ponto de gerar pressões "expansionistas", propondo assim a fixação de um limite máximo de $50 \%$ sobre a cota. Apesar do manifesto interesse de reforma por parte de várias delegações, ingleses e norte-americanos "receando os efeitos sobre a opinião pública, sempre apreensiva pela concessão excessiva de crédito" (SC.1944.05.08.mf.dg - II-13, 1944: 35), articularam apoio suficiente para conter as tentativas de alteração.

Assim, Souza Costa e os demais membros da delegação brasileira julgaram por bem não insistir na ampliação do limite 
de percentagem, e sim pressionar para que o Fundo assumisse o compromisso de ampliar os recursos a serem disponibilizados por intermédio da waiver clause, que ficou redigida nos seguintes termos: "The Fund may in its discretion, and on terms which safeguard its interests, waive any of the conditions (...) especially in the case of members with a record of avoiding large or continuous use of the Fund's general resources", o que significava dizer que, em alguma medida, em consonância com a proposta francesa, países-membros que usassem com parcimônia os recursos do Fundo passariam a ter maiores chances de recorrer à waiver clause. Além disso,

The Fund shall also take into consideration a member's willingness to pledge as collateral security acceptable assets having a value sufficient in the opinion of the Fund to protect its interests and may require as a condition of waiver the pledge of such collateral security (IMF, 1945: 10).

A aprovação da waiver clause nos Articles of Agreement do Fundo foi comemorada pela imprensa brasileira;

Com a cláusula de exclusão de limitações, pleiteada pelo Brasil, e alcançada, para o caso de desequilíbrio na balança de pagamentos proveniente de fortes desajustamentos de preços entre produtos importados e exportados, ficarão os países exportadores de produtos agrícolas mais protegidos (SC.1944.05.08.mf.dg - I-54, 1944).

\section{A delegação brasileira, a reconstrução da Europa e a busca de oportunidades para a agroexportação e para a exploração de recursos naturais}

Ficava claro àquela altura que um importante princípio norteador da atuação da delegação brasileira nos acordos de Bretton Woods estava centrado no reconhecimento da especificidade do Brasil diante das principais nações envolvidas 
na construção da nova ordem econômica, e principalmente na tentativa de garantir decisões que favorecessem os rendimentos do setor agroexportador, gerador de divisas indispensáveis para o processo de substituição de importações em curso (IANNI, 1977). O esforço para tentar elevar o volume de crédito a ser disponibilizado pelo Fundo Monetário Internacional foi orientado por esta perspectiva; ainda que as aspirações da delegação brasileira não tenham sido vitoriosas, a waiver clause foi considerada um ganho importante. Entretanto, a pressão pelo reconhecimento das necessidades específicas dos países agroexportadores no "sistema Bretton Woods" não terminava ali. Os delegados do Brasil também pleitearam na Conferência Monetária e Financeira das Nações Unidas o planejamento para a fundação de instituições voltadas para "manter a regularização da oferta" de bens agrícolas no mercado internacional. Alegava a representação brasileira que o emprego e a estabilidade do sistema poderiam ser severamente abalados por "fluctuations in primary products resulting from climatic or other factors, with a resulting disequilibrium in relative prices capable of endangering the whole price structure" (SC.1944.05.08.mf.dg II-13, 1944: 40), e que portanto o mercado de bens primários deveria ser protegido por um aparato institucional multilateral similar ao utilizado para o mercado de câmbio. Apesar dos esforços, contudo, a proposição não encontrou eco entre as demais delegações: "Infelizmente, a comissão incumbida de examinar esses problemas foi forçada a fazer uma série de recomendações, perdendo de muito a ênfase que se deveria dar à proposta do Brasil" (SC.1944.05.08.mf.dg - II-13, 1944: 40).

Isto contudo não encerrava o esforço em busca de garantias para o setor agroexportador, que, se por um lado, abandonava a luta por conquistas estruturais através do diálogo multilateral; por outro, voltava-se para a obtenção de concessões mais imediatas, a partir de uma estratégia bilateral direcionada para as relações com os Estados Unidos. Durante a Conferência de Bretton Woods foi encaminhado pela delegação brasileira à delegação americana um plano de elevação da produtividade agrícola a partir da importação de máquinas norte-americanas. 
A pertinência do plano fora justificada como parte fundamental da política de guerra das Nações Unidas, "which does not follow the pattern of conquest and greed" e que portanto "implies the supplying of food for the liberated populations". Isto faria do Brasil peça-chave nos esforços humanitários, "with the faith which is expressed in the wealth of its soil and the widening of its cultivated products". Na medida em que a exportação de alimentos não poderia ser feita ameaçando o consumo interno, "this increase in production becomes further necessary as one of the outstanding mediums in the fight against inflation, which is a threat to any country, involved in the war effort". Assim, concluíam os técnicos brasileiros que o atendimento da demanda por alimentos necessitaria de "intensive mechanization of agriculture", na medida em que a elevação do emprego do fator trabalho no campo não seria possível dado que

a large section of men has entered the armed forces of [Brazil], as well as the amount of men absorbed by the war industries, in the intensive mining regions of strategic products, in the rubber extraction in the Amazon, in substante, in the provision of labor for war industries and essential public works of a military and strategic character (SC.1944.05.08.mf.dg - II-26, 1944) .

estaria pressionando negativamente a oferta de mão-de-obra para o setor agrícola. Para o sucesso do programa de elevação da produtividade agrícola brasileira,

"an authorization must be obtained which will permit american industry to produce and supply the Brazilian Goverment with the necessary machinery to put this plan into execution. The agricultural machines existent in our country are not sufficient in number for the amplification of all areas" (SC.1944.05.08.mf.dg II-26, 1944).

Com as máquinas, pretendia o governo brasileiro ampliar a produção de milho, feijões, arroz, amendoim e legumes, e para tal, solicitavam licenças de importação para 
1) 400 medium tractors for plowing and disking; 2) 400 plows for same; 3) 400 harrows for same; 4) 150 small tractors, with respective equipment for plowing, disking, seeding, cultivating and cutting; (4)100 6-ton trucks - for the transportation of machinery from farm to farm; 6) 40 large tractors, equipped for underbrush cleaning; 7) 20 large tractors, equipped for draining service; 8) 150 combines for harvesting and rice threshing; 9)100 combines for corn harvesting and shelling; 10) 150 bean shelling machines, equipped with internal combustion engines (SC.1944.05.08.mf.dg - II-26, 1944).

Assim, se falharam os esforços para alterar a redação dos Artigos do Acordo do Fundo Monetário Internacional, no campo das concessões imediatas a delegação brasileira foi bem sucedida, uma vez que, em linhas gerais, o plano de elevação da produtividade agrícola por meio da importação de máquinas foi acatado pelos Estados Unidos, o que pode-se atestar em telegrama de Souza Costa ao presidente Vargas, datado de 27 de julho de 1944 (momento final dos trabalhos da Conferência), no qual lemos que

apesar de grande dificuldades conseguimos [a] promessa [de] sermos atendidos no seguinte: tratores médios, arados e grades poderão entregar 200 de cada um até 01/07/1945, e o saldo no 3oㅡㄴ trimestre de 1945. Tratores pequenos equipados para arar, discar, semear, cortar e cultivar poderão ser entregues 150 pedidos no $1^{\circ}$ e $2^{\circ}$ trimestre de 1945. Conjuntos para colher e bater arroz e milho, a entrega de 200 pedidos salvo força maior poderá ser feita no $3^{\circ}$ e $4^{\circ}$ trimestres de 1945 . Sobre as 150 batedeiras de feijão com os equipamentos consideram imprecisa a descrição feita e esclarecem que se for sem motor poderão entregar no $2^{\circ}$. trimestre (SC.1944.05.08.mf.dg - II-1, 1944).

Souza Costa solicita, contudo, o empenho do governo brasileiro para cumprir as condições apresentadas pelos Estados Unidos, que para "considerarem oficialmente [o] pedido" solicitaram que "o Ministro da Agricultura [apresentasse] até 15 de agosto (...) programa completo com todas as especificações", 
ATUAÇÃO DA DELEGAÇÃO BRASILEIRA NA FORMULAÇÃO...

além de "declarações das zonas onde serão empregadas [as máquinas]" SC.1944.05.08.mf.dg - II-1, 1944).

Em paralelo às negociações acerca das máquinas agrícolas, a delegação brasileira também informa a Getúlio Vargas acerca dos embarques de maquinário ferroviário e de extração mineral, para os quais não foram encontrados registros dos acordos que os antecederam. Em telegrama de 27 de julho de 1944, Souza Costa informa que

136 eixos de aço torneados para rodas de jogo e rodas motrizes de locomotivas já foram embarcados. Chapas, tubos e restante material estão sendo embarcados agora. Rodas de carros de passageiros e rodas de vagões em numero de 78 constantes [em] lista SC.1944.05.08.mf.dg - II-8, 1944) .

Em outro telegrama, o coronel João Carlos Barreto, presidente do Conselho Nacional do Petróleo, solicita a Souza Costa que aproveite os avanços na Conferência para tecer articulações de modo a

obter o fornecimento necessário dos materiais necessários ao serviço de perfuração dos campos petrolíferos da Baía (sic). Esses materiais incluem: equipamento suplementar (...); acessórios para conservação do material já existente na Baia e portanto não previsto (...); caminhões e tratores indispensáveis a manutenção e ao transporte. Materiais para substituírem os perdidos no 'Brasiloide', afundado por ação do inimigo, conforme já é do conhecimento do governo americano (SC.1944.05.08.mf.dg - II-7, 1944).

Por fim é o próprio Vargas que solicita ao Ministro Souza Costa que "verifique a possibilidade de aquisição, preço e prazo de entrega" de "dragas de sucção e arrasto autotransportadoras" para "o serviço de melhoramento de Portos" (SC.1944.05.08.mf.dg - II-9, 1944). 


\section{O Brasil e a controvérsia sobre os objetivos do Banco Internacional de Reconstrução e Desenvolvimento}

Restava ainda definir os termos de fundação do Banco de Reconstrução e Desenvolvimento. Algumas delegações presentes em Bretton Woods viram a conferência como uma rara oportunidade de pressionar no sentido de que a nova ordem econômica internacional fosse dotada de instituições que tivessem por prioridade o pleno emprego e o desenvolvimento não necessariamente a reconstrução das economias arrasadas pela guerra, mas o desenvolvimento de economias até aquele momento consideradas "atrasadas". Vimos que a delegação inglesa insistiu em demonstrar seu posicionamento favorável ao full employment. Fora do centro do mundo capitalista, a delegação indiana chegara a propor que o próprio Fundo Monetário Internacional atuasse como instituição de fomento ao desenvolvimento econômico através de empréstimos bancários. Foi a delegação brasileira a primeira a se pronunciar contra a iniciativa indiana, respaldada em sua dupla preocupação de restaurar o equilíbrio financeiro internacional (o que significaria, neste momento, prudência quanto à tendências "expansionistas") e zelar pela solidez das instituições multilaterais em formação. Segundo Gudin:

eu fui o primeiro a levantar na assembléia e protestar. Disse: não, o Fundo não será feito para isto, para isto existe o Banco. O Fundo está sendo feito para procurar, a prazo relativamente curto, consertar os desequilíbrios nas balanças internacionais e procurar manter paridade das moedas" (E16, 1979: 131).

Assim, se era mantida a idéia de que as funções do Fundo não seriam flexibilizadas, surgia entre as delegações grande expectativa quanto à criação do BIRD, que pela sua natureza tenderia a ser uma instituição muita mais voltada para o fomento produtivo que um fundo de estabilização monetária.

A delegação indiana, percebendo a pouca receptividade de sua proposta de uso dos recursos internacionais para programas 
de desenvolvimento, voltou à carga mais uma vez decidindo apelar pela inserção de cláusula garantindo o uso dos recursos do Fundo e do Banco para a liquidação de saldos congelados na Inglaterra durante a Guerra Mundial - recursos que, legal e moralmente lhes pertenciam - com os quais o governo indiano pretendia, então, "reajustar seu equipamento industrial". É evidente que a Índia teve de aceitar mais uma derrota na medida em que a delegação britânica, ciente das agruras da tarefa da reconstrução no pós-guerra, movera suas forças no sentido de obstar o avanço da proposta, no que teve sucesso. Segundo Souza Costa,

O Banco tem como finalidade precípua a reconstrução dos países devastados. A Índia não está neste caso, mas se encontra em situação de dificuldade, devido aos seus produtos de exportação estarem congelados na Inglaterra. Por isso sentia-se com direito a recorrer as facilidades de crédito do fundo do Banco, o qual, entretanto, como já disse, tem como principal finalidade a reconstrução dos países devastados pela guerra (SC.pi.Costa.S.1944.09.19, 1944: 28-29).

O purismo de Gudin em Bretton Woods quanto às funções do Fundo não pode nos afastar do fato de que partiu da representação brasileira em Atlantic City uma proposição igualmente "flexibilizadora", não em relação ao FMI mas ao BIRD, que se não invocava as necessidades do "desenvolvimento" como argumento para acessar os seus recursos, relacionava investimentos em determinados ramos do setor exportador à estabilidade financeira. Bulhões recorreu não ao problema dos desequilíbrios em balanço de pagamentos temporários, mas àqueles desequilíbrios que "se mantém por tempo indefinido", para os quais "a concessão de recursos a curto prazo e sem ligação direta a novos investimentos só pode agravar a situação futura do comércio exterior do país". Assim, nestes casos "a primeira providência é praticamente impossível sem uma entrada de capitais para o desenvolvimento de novas fontes produtoras" (SC.1944.05.08.mf.dg - II-13, 1944: 20), o que 
significa dizer, neste caso, que investe-se não com finalidade "desenvolvimentista", mas com o intuito de permitir a expansão de um setor capaz de manter em equilíbrio as contas externas de um país.

Mesmo entendendo que "a organização do Banco de Reconstrução e Desenvolvimento não é propriamente para esse fim", a delegação brasileira procurou maneiras de garantir que o BIRD atuasse juntamente com o FMI na resolução de determinados impasses surgidos em economias cuja necessidade de estimulo às exportações fosse manifesta. Para tal, a delegação brasileira contou com o apoio da delegação britânica no sentido de propor um dispositivo que previa empréstimos "excepcionais" para fins não-convencionais, voltados para a manutenção da estabilidade monetária. O dispositivo foi elaborado pelo próprio Lord Keynes, e ganhou a seguinte redação: "In exceptional circumstances, the Bank, acting in agreement with the International Monetary Fund and in support of its policy, may make or guarantee a loan which is not tied to any particular Project but is designed to foster the general capacity of a member country to recover equilibrium in its balance of payment by expansion of exports and in other ways" (SC.1944.05.08.mf.dg - II-13, 1944: 21). Alegava Bulhões que os empréstimos para reconstrução ou desenvolvimento, atividade principal prevista para $\mathrm{O}$ BIRD, poderiam não ser empréstimos diretamente necessários à recomposição do balanço de pagamentos, mas que ao permitir, por exemplo, a produção de um novo artigo agrícola de exportação em substituição a um produto sem mercado no estrangeiro, dariam solidez às contas externas no médio ou longo prazo. Neste caso, o investimento "não é propriamente um caso de 'projeto específico de reconstrução ou desenvolvimento'. Trata-se de investimento especial que não constitui 'reconstrução', nem chega a ser "desenvolvimento" (SC.1944.05.08.mf.dg - II-13, 1944: 22). Assim, na intenção de estabelecer conexão entre os recursos de curto prazo do FMI e os investimentos de longo prazo do BIRD, o Brasil propôs a seguinte emenda à Joint Statement no encontro de Atlantic City: "To correlate procedures 
for exchange stability with a policy for the promotion of international investment by other international financial agencies and to evolve a working relationship with such agencies". Apesar dos esforços, o dispositivo brasileiro não foi mantido; pactuara-se em Atlantic City que o texto a ser encaminhado para Bretton Woods não faria menção à política do Fundo Monetário Internacional ou do Banco de Reconstrução e Desenvolvimento, mas somente aos seus objetivos. "De fato, o acordo de Bretton Woods não fala mais em "purposes and policies of the Fund", mas tão somente em "purposes" (SC.1944.05.08.mf.dg - II-13, 1944: 22).

Assim, todas as iniciativas no sentido de ampliar, de uma forma ou de outra, as atribuições do Banco de Reconstrução e Desenvolvimento - juntamente com o Fundo Monetário Internacional - foram obstadas em Bretton Woods, o que levara Souza Costa a afirmar que

havemos de convir que o Banco será primordialmente um Banco de Reconstrução e Desenvolvimento de caráter especial e, conseqüentemente, seus recursos, salvo num ou noutro caso, não serão destinados a investimentos normais, que competem às instituições privadas (SC.1944.05.08.mf.dg - II-13, 1944: 22).

Assim, evidenciava-se, contra a expectativa de muitas delegações, que o BIRD seria quase que exclusivamente uma instituição voltada para auxiliar os países devastados pela guerra ou socorrer emergencialmente aqueles países, também destruídos, que estivessem sofrendo desequilíbrios graves em decorrência de modificações em sua estrutura econômica ocasionadas pelo conflito. Reconhecia Bulhões, em telegrama, que "se pleitearmos e conseguirmos garantia [de] recursos no Fundo, não nos é dado esperar do Banco [de] Reconstrução para os próximos anos. Nessa instituição maiores facilidades devem ser dadas [aos] países europeus" (SC 1944.05.08.mf.dg - I-58, 1944).

O fato causou evidente desânimo entre muitas delegações, especialmente latino-americanas, que "verificando (...) que os recursos do Banco seriam aplicados na Europa" iniciaram um 
amplo movimento de recuo, visando "não contribuir para o Banco" (SC.1944.05.08.mf.dg - II-13, 1944: ${ }^{36)}$. A própria representação brasileira em Bretton Woods demonstra claro sinal de decepção quanto às possibilidades perdidas: "Organização do Banco foi assunto das reuniões de hoje. Sentese que a sua finalidade principal é facilitar investimentos para [a] reconstrução da Europa (...) Neste caso, não me parece que tenhamos tão direto interesse como no Fundo", o que contudo não levara o Brasil à sinalizar com um boicote, tal como teriam feito algumas delegações latino-americanas: "Atendendo entretanto a que as resoluções aqui tomadas dependem da aprovação dos respectivos governos, aceitaremos ad referendum a mesma quota" (SC.1944.05.08.mf.dg - I-59, 1944). Lembraria Souza Costa semanas depois, em seu discurso à Associação Comercial de São Paulo que

todos queriam cotas menores, porque a finalidade desse instituto era reconstruir a Europa, e não havia interesse maior em emprestar capitais. Todas as nações que antes [na ocasião de discutir as cotas do FMI] falavam em grandes saldos de ouro, na ocasião de subscrever para o Banco entraram em verdadeira marcha ré: ninguém tinha nada... (SC.Costa,S.pi.1942.04.30, 1944: 40).

Mesmo a delegação soviética, particularmente interessada no tema da reconstrução, decidiu não subscrever a cota inicialmente estipulada em US\$ 1200 milhões, acedendo, contudo, com o valor de US\$ 900 milhões. Segundo Souza Costa, esta conjugação de episódios teria levado as delegações norteamericana e britânica a fazerem "um apelo aos demais países para que concordassem em aumentar as suas quotas", o que foi atendido pela China e pelas delegações latino-americanas (estas últimas elevando sua participação em 10\% no Banco), mas não em escala suficiente a ponto de prevenir que os Estados Unidos fossem obrigados a aumentar a sua cota para US\$ 3175 milhões (SC.1944.05.08.mf.dg - I-69, 1944).

Ainda que a delegação brasileira demonstrasse seu 
desapontamento quanto ao BIRD, Souza Costa iniciou um movimento de oposição contra o boicote ao Banco, sustentando em linhas gerais a tese de que a cooperação entre as nações "exige certo desprendimento" de modo que "não podemos ceder para ganhar imediatamente". Além disso, alega que a reconstrução da Europa seria uma "garantia de estabilidade e liberdade do comércio internacional", e neste sentido, "quanto maior for o número de países capazes de comerciar, comprando e vendendo, tanto melhor será a posição econômica dos países latino-americanos", apontando então para o que seria o cerne de sua argumentação: uma Europa reconstruída era um mercado reconstruído para as exportações latino-americanas. Em suas palavras:

Não era possível (...) cogitar do restabelecimento da ordem econômica do mundo, deixando de lado (...) um conglomerado de tal magnitude de massa do mundo. $\mathrm{O}$ que isto representa como mercado de consumo é formidável (...) Se examinarmos o fato em relação à economia do Brasil e tomarmos os números de 1938, chegaremos também a conclusões edificantes quanto a importância de levar em conta esse mercado (SC.Costa,S.pi.1942.04.30, 1944: 31).

Souza Costa esperava ainda que a orientação eurocêntrica do BIRD fosse ser revertida tão logo os esforços de reconstrução fossem esgotados, o que permitiria que "mais tarde [fossem] amplos os recursos para os programas de desenvolvimento", e que mesmo que a escassez de recursos dos países latinoamericanos justificasse a redução de suas contribuições ao Banco, "de qualquer forma [seria] indispensável contribuir" (SC.1944.05.08.mf.dg - II-13, 1944: 36).

Souza Costa esclareceu posteriormente outro argumento importante que fundamentou a defesa, por parte da delegação brasileira, da pertinência desta instituição multilateral. Considerando ter sido o projeto do BIRD "muito bem traçado e com resultados seguros", buscou gerar uma postura de confiança alegando que "não vai ser o nosso ouro que 
reconstruirá a Europa", dado que as operações de financiamento não seriam realizadas utilizando-se dos 10 bilhões de dólares que formam o capital do Banco, constituído pelas cotas nacionais. "O objetivo é lançar o Banco, dar-lhe forma para entrar nos mercados de capitais, tomando-os onde houver, com seu endosso, que é do mundo, de todas as nações, para destinálos as operações de reconstrução". Desta forma, o capital formado pela subscrição das cotas seria somente "uma espécie de garantia, (...) uma segurança de suas transações". Além disso, argumentava que as cotas não deveriam ser pagas integralmente em ouro; somente $2 \%$ dela seguiria em ouro, e o restante em moeda nacional. "Conseqüentemente, $98 \%$ de nossa cota só poderão ser aplicados no Brasil ou para efeito de compras aqui e apenas $2 \%$ em ouro, isto é, 2 milhões de dólares, constituirão uma cota mínima, ou seja, uma contribuição simbólica" (SC.pi.Costa.S.1944.09.19, 1944: 40-41). A partir da defesa deste ponto de vista os demais países latino-americanos optam por ceder ao apelo da delegação norte-americana, contribuindo com cota menor que aquela subscrita junto ao FMI, mas mantendo sua participação nos esforços de reconstrução.

A Conferência de Bretton Woods encerrou-se com a surpreendente mudança no posicionamento da delegação soviética, que recebeu ordens expressas do Kremlin, na última hora, para restabelecer a subscrição de US\$ 1200 milhões de dólares junto ao Banco de Reconstrução e Desenvolvimento, fato que é narrado por Bulhões em telegrama de 23 de julho de 1944: "Essa notícia teve grande repercussão [e] foi imediatamente secundada. [Os] Estados Unidos propuseram [a] retificação [da] subscrição [ao] aceitar [a] decisão [dos] soviéticos, o que foi aceito unanimemente". E Bulhões acaba por compartilhar com os norte-americanos da crença de que haveria um mundo pósguerra no qual a União Soviética integraria pacificamente a ordem econômica internacional capitalista (NAU, 1992: 95): "Fato teve grande repercussão [e] mostra (...) bem claro [a] direção [que] vai tomando a Rússia, volvendo [ao] concerto [e à] cooperação com [a] economia [dos] países chamados capitalistas" (SC.1944.05.08.mf.dg - I-72, 1944). Mas Souza Costa 
desconfia: "Já eu achava uma grande coisa meter o russo no Banco...mas, que ele aumentasse a cota, francamente, nunca supus. Mas a diplomacia inglesa tem esses milagres" (SC.pi.Costa.S.1944.09.19, 1944: 41).

Enfim, o saldo das negociações foi visto como positivo pela delegação brasileira. Ao contrário do entendimento de grande parte da literatura contemporânea, influenciada pelo declínio do sistema Bretton Woods nos anos 1970, Souza Costa foi enfático ao definir que a Conferência e as negociações que lhe antecederam traçaram "um sentido novo na evolução do pensamento econômico", na medida em que

concluiu objetivamente (...) uma declaração conjunta que poderá ser considerada imperfeita em alguns de seus pontos, mas que representa sem dúvida o que de melhor se poderia fazer em matéria que nos tempos que correm obriga considerações de ordem política (SC.1944.05.08.mf.dg - II-13, 1944: 40).

Gudin defendia que a fórmula de Bretton Woods "não favoreceu ninguém" e "nem era para isso" (E16, 1979: 130); sua instauração fora considerada uma vitória dos princípios emanados pela delegação brasileira na medida em que consagrara a estabilidade cambial e a institucionalização do sistema econômico internacional, os dois principais pontos de vista defendidos ao longo de todas as rodadas de negociação.

\section{Agradecimentos}

A pesquisa que fundamentou este artigo não teria sido possível sem o apoio do Centro de Pesquisa e Documentação de História Contemporânea do Brasil da Fundação Getúlio Vargas (CPDOC-FGV). Agradeço aos professores Vania Maria Cury (IEUFRJ), André Vilella (EPGE-FGV), Bernardo Kocher (PPGH-UFF) e Matias Spektor (CPDOC-FGV) pela importante interlocução. Naturalmente, as falhas neste artigo são de minha total responsabilidade. 


\section{Referências Bibliográficas}

ABREU, Alzira et alli (coord). Dicionário Histórico-Biográfico Brasileiro (pós-1930). Rio de Janeiro: FGV, 2000. CD-Rom.

ABREU, Marcelo de Paiva. Brazil, the GATT, and the WTO: history and prospects. Departamento de Economia da PUC-Rio - Textos para Discussão. n. 392, set 1998.

Disponível em <http://www.econ.puc-rio.br/pdf/td392.pdf >. Acesso em: 20 jun. 2008.

. The Brazilian Economy, 1928-1980. Departamento de Economia da PUC-Rio - Textos para Discussão. n. 433, nov 2000. Disponível em <http://www.econ.puc-rio.br/pdf/td392.pdf>. Acesso em: 20 jun. 2008. (org). A Ordem do Progresso: cem anos de política econômica republicana (1889-1989). Rio de Janeiro: Elsevier, 1990.

ALMEIDA, Paulo Roberto de. O Brasil e as Crises Financeiras Internacionais (1929-

1999). Múltipla. Brasília, v.5, n.7, pp. 71-108, 1998.

BIELSCHOWSKY, Ricardo. Eugenio Gudin. Estudos Avançados. São Paulo. v.15, n.41, pp. 91-110, 2001.

BORDO, Michael. The Bretton Woods International Monetary System: an historical overview. NBER Working Papers. Mar 1992, n. 4033. Disponível em http://www.nber.org/papers/w4033. Acesso em: 20 jun. 2008

EICHENGREEN, Barry. A Globalização do Capital: uma história do sistema monetário internacional. São Paulo: Editora 34, 2000.

IANNI, Octavio. Estado e Planejamento Econômico no Brasil (19301970). $2^{a}$ ed. Rio de Janeiro: Civilização Brasileira, 1977.

LICHTENSZTEJN, Samuel e BAER, Mônica. Fundo Monetário Internacional e Banco Mundial: estratégias e políticas do poder financeiro. São Paulo: Brasiliense, 1987.

MAYER, Jorge Miguel. Artur de Sousa Costa. IN: ABREU, Alzira et alli (coord). Dicionário Histórico-Biográfico Brasileiro (pós-1930). Rio de Janeiro: FGV, 2000,

CD-Rom.

McKINNON, Ronald. The Rules of the Game: international money in historical

perspective. Journal of Economic Literature. v. XXXI, n. 31, pp. 1-44, 1993. 
NAU, Henry R. O Mito da Decadência dos Estados Unidos: a liderança americana na economia mundial na década de 1990. Rio de Janeiro: Jorge Zahar Editor, 1992.

SARETTA, Fausto. Octavio Gouvêa de Bulhões. Estudos Avançados. São Paulo. v.15, n.41, pp. 111-125, 2001.

SOLOMON, Robert. O Sistema Monetário Internacional (1945-1976). Rio de Janeiro: Zahar, 1979.

\section{Fontes Primárias (Arquivos do CPDOC)}

GV c 1944.07.01/2 - Correspondência - 01/07 a 12/08/1944. Telegramas de Sousa Costa a Getúlio Vargas sobre a Conferência de Bretton Woods relatando o andamento dos debates da Comissão encarregada da criação do Fundo Monetário Internacional e as discussões em torno do capital do Fundo, da subscrição de ações, das quotas de participação do Brasil e outros países e da direção do Fundo. Inclui consulta de Sousa Costa quanto ao convite para visitar o México; informações sobre seus contatos em Washington e telegrama de Roosevelt a Getúlio Vargas agradecendo a colaboração de Sousa Costa. Bretton Woods, Washington E16 - Entrevista com Eugênio Gudin II. Data: 03/07/1979 a 24/08/1979 Duração: 20h55min

SC.1944.05.08.mf.dg - I-47 - Secretaria de Estado das Relações Exteriores. Telegrama expedido de Bretton Woods em 10 de julho de 1944 - Confidencial - Remetente Arthur da Souza Costa / Destinatário Getúlio Vargas.

SC.1944.05.08.mf.dg - I-54 - Telegrama da Delegação Brasileira: serviço especial para o Jornal "A Noite".

SC.1944.05.08.mf.dg - I-57 - Secretaria de Estado das Relações Exteriores. Telegrama expedido de Bretton Woods - Confidencial Remetente Arthur da Souza Costa / Destinatário Getúlio Vargas SC 1944.05.08.mf.dg - I-58 - Telegrama de Otávio Gouvea de Bulhões sem destinatário

SC.1944.05.08.mf.dg - I-59 - Telegrama de Souza Costa para Getúlio Vargas expedido em 16/07/1944.

SC.1944.05.08.mf.dg - I-69 - Telegrama de Souza Costa para Getúlio Vargas - 21/07/1944.

SC.1944.05.08.mf.dg - I-72. Telegrama de Otávio Gouvea de Bulhões. 23 de julho de 1944. 
SC.1944.05.08.mf.dg - II-1. Embaixada do Brasil em Washington. Telegrama expedido pelo Ministro Souza Costa para Getúlio Vargas em 27 de julho de 1944.

SC.1944.05.08.mf.dg - II-7. Embaixada do Brasil em Washington. Telegrama recebido pelo Ministro Souza Costa, enviado pelo coronel João Carlos Barreto em 02 de agosto de 1944.

SC.1944.05.08.mf.dg - II-8; Embaixada do Brasil em Washington. Telegrama expedido pelo Ministro Souza Costa para Getúlio Vargas em 27 de julho de 1944.

SC.1944.05.08.mf.dg - II-9. Embaixada do Brasil em Washington. Telegrama recebido pelo Ministro Souza Costa, enviado pelo presidente Getúlio Vargas em 04 de agosto de 1944

SC.1944.05.08.mf.dg - II-13. Relatório da Delegação Brasileira à Conferência de Bretton Woods ao Excelentíssimo Senhor Presidente da República Getúlio Vargas, apresentado pelo Presidente da Delegação Brasileira Ministro Souza Costa.

SC.1944.05.08.mf.dg - II-23 - Manuscrito de trabalho intitulado "Críticas". Arquivo pessoal do Ministro Souza Costa. 1944

SC.1944.05.08.mf.dg - II-26 - Documento sem título ou autor.

SC.1944.05.08.mf.dg.II-39. Manuscrito

SC.1944.05.08.mf.dg.II-40. Manuscrito

SC pi Bulhões, O. 1944.08.14 - Série: pi - Produção intelectual 14.08.1944. "A Conferência Monetária de Bretton Woods". Estudo de Octávio Gouvêa de Bulhões

SC.Costa,S.pi.1942.04.30 - Discurso do Ministro da Fazenda Arthur da Souza Costa na Associação Comercial de São Paulo (8/05/1944).

SC.pi.Costa.S.1944.09.19 - "Conferência Internacional Monetária Bretton Woods". Conferência proferida por Sousa Costa na Escola do Estado Maior do Exército. 19/09/1944

\section{Fontes publicadas}

IMF. Articles of Agreement of the International Monetary Fund. Adopted at the United Nations Monetary and Financial Conference, Bretton Woods, New Hampshire, July 22, 1944. Entered into force December 27, 1945. Disponível em http://www.imf.org/external/pubs/ft/aa/aa.pdf.

Acesso em: 20 jun. 2008. 
ATUAÇÃO DA DELEGAÇÃO BRASILEIRA NA FORMULAÇÃO...

BARREIROS, Daniel de Pinho. The Brazilian Delegation in the Making of the Bretton Woods International Agreements (19421944). História, v.28, n.2, p.515-570, 2009.

\begin{abstract}
The aim of this article is to analyse the economic ideas and the diplomatic action of the Brazilian delegates in the United Nations Monetary and Financial Conference, which took place in Bretton Woods, in July, 1944. The article highlights the experience of Octavio Gouvea de Bulhões, Eugenio Gudin and the Brazilian Minister of Finance at that time, Souza Costa. The study is centered on the new economic order conception displayed by the Brazilian delegates, as well as on their pragmatic alignment with the forces in struggle, organized according to the White Plan (North-american) and the Keynes Plan (British). The article concludes that, in spite of being unable to halt the integral approval of the White Plan, Brazilian delegates were able to assure seats in the new economic institutional mechanisms created in the Bretton Woods Conference.
\end{abstract}

Keywords: Bretton Woods; Eugenio Gudin; Octavio Bulhões; Souza Costa; International economy.

\title{
NOTAS
}

${ }^{1} \mathrm{O}$ relatório aparece assinado por Souza Costa, mas temos relevantes indícios de que toda a seção relativa à analise da atuação da delegação brasileira em Bretton Woods e nos encontros que lhe sucederam, foi redigida por Otávio Gouvea de Bulhões. Isto porque, em seus arquivos pessoais depositados no Centro de Pesquisa e Documentação de História Contemporânea do Brasil (CPDOC-FGV), pode ser encontrado documento assinado por Bulhões, datilografado em papel timbrado da Seção de Estudos Econômicos e Financeiros do Ministério da Fazenda, cujo texto é fiel ao encaminhado no relatório do Ministro Souza Costa ao presidente Getúlio Vargas. Tal idéia confirma em parte as palavras de Eugenio Gudin, outro ilustre membro da delegação brasileira, que em entrevista a pesquisadores do CPDOC, afirmou que "quem 
trabalhava no batente, de fato, acompanhando as sessões, éramos o Bulhões e eu". Para o texto de Bulhões, ver nos arquivos do CPDOC o documento de referência SC.pi.Bulhões.O.1944.08.14. Para a entrevista de Gudin, consultar no CPDOC o volume de referência E.16, página 127.

Artigo recebido em 02/2009. Aprovado em 08/2009. 